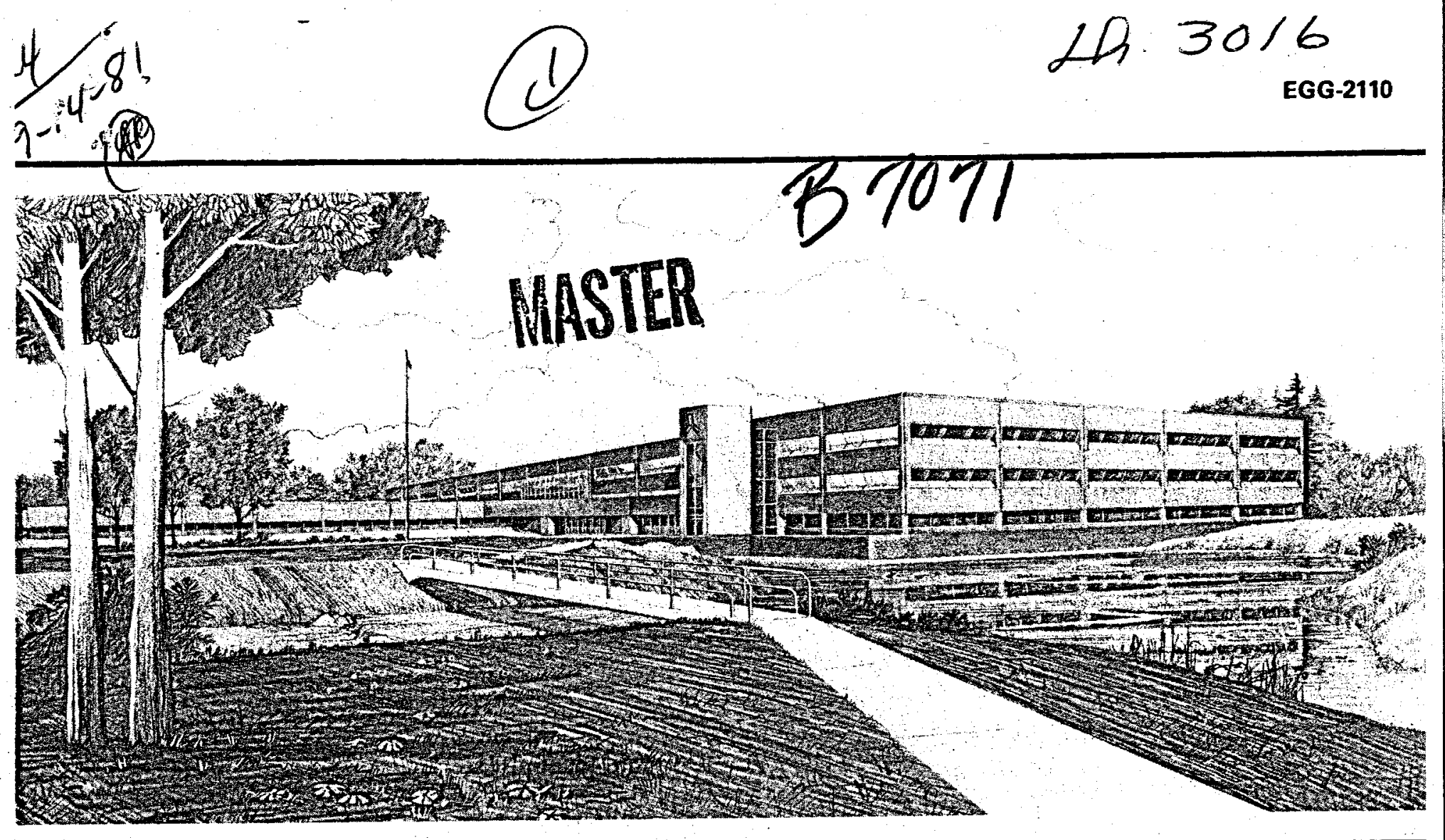

U.S. Department of Energy

Idaho Operations Office - Idaho National Engineering Laboratory

\title{
Semiannual Progress Report for the Idaho Geothermal Program October 1, 1980, to March 31, 1981
}

John T. Parker, Ed.

Carla J. Smith, Ed.

September 1981 
Printed in the United States of America Available from

National Technical Information Service

U.S. Department of Commerce

5285 Port Royal Road

Springfield, Virginia 22161

NTIS Price Codes: Printed Copy 103

Microfiche $\mathrm{AO1}$

\section{DISCLAIMER}

This book was prepared as an account of work sponsored by an agency of the United States Government. Neither the United States Government nor any agency thereof, nor any of their employees, makes any warranty, express or implied, or assumes any legal liability or responsibility for the accuracy, completeness, or usefulness of any information, apparatus, product or process disclosed, or represents that its use would not infringe privately owned rights. References herein to any specific commercial product, process, or service by trade name, trademark, manufacturer, or otherwise, does not necessarily constitute or imply its endorsement, recommendation, or favoring by the United States Government or any agency thereof. The views and opinions of authors expressed herein do not necessarily state or reflect those of the United States Government or any agency thereof. 


\section{SEMIANNUAL PROGRESS REPORT FOR THE IDAHO GEOTHERMAL PROGRAM}

October 1, 1980, to March 31, 1981

John T. Parker, Ed.

Carla J. Smith, Ed.

Published September 1981

EG\&G Idaho, Inc. Idaho Falls, Idaho 83415

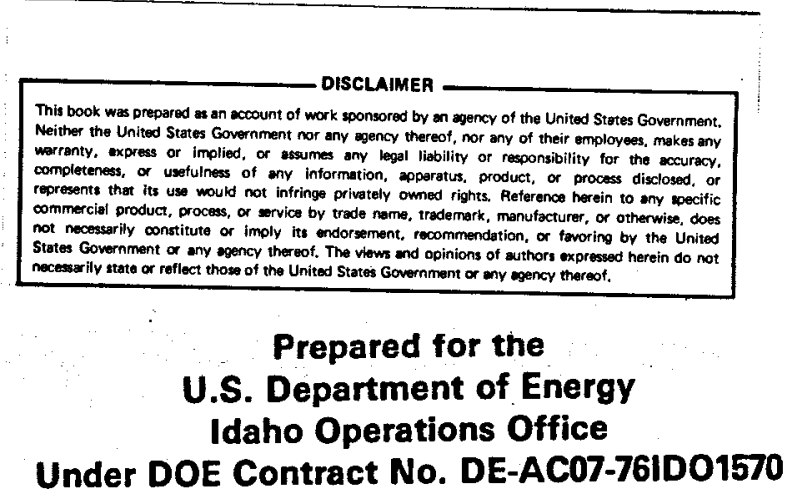

DISTRIBUTIOH OF THIS DOCUMENT IS UNLIMITED 


\section{ABSTRACT}

This document summarizes progress of the Idaho Geothermal Program from October 1, 1980, to March 31, 1981. The report summarizes modifications incorporated in the 5-MW Pilot Power Plant at Raft River Geothermal Test Site, system operational testing, and maintenance activities at that plant; the water treatment program's corrosion studies. Progress is reported on performance tests of the ORNL condenser in the Prototype Power Plant, checkout of the directcontact heat exchanger, and modification of that plant. The progress of testing and continuing studies of direct-contact heat exchangers is reported-including the liquid-liquid directcontact heat exchanger, primary heat exchanger, sieve tray preheater, multiple-purpose apparatus, and packed bed studies and tests. Effects of production-injection tests at Raft River on monitor wells are summarized. The report describes monitoring activities and studies of the environmental program at Raft River and summarizes plans of two successful proposers under the User-Coupled Confirmation Drilling Program. Investigation of costs for three aspects of direct use of hydrothermal energy is reported. Progress is reported on the Marketing Assistance Program, through which technical information and assistance are provided to potential users and developers of geothermal resources. Also reported is progress on DOE's 12 Program Opportunity Notice (PON) Program demonstration projects and the 10 Program Research and Development Announcement (PRDA) Program study projects.

Three new tasks/programs are described, including initial activities and future plans:

1. Evaluation of advanced technologies for application in an advanced binary geothermal plant.

2. Development of testing and analysis methods for low-to-moderate temperature hydrothermal resources.

3. Geothermal applications development for the M-X missile system's Renewable Energy Systems (RES) package. 


\section{SUMMARY}

The objectives of the Idaho Geothermal Program, sponsored by the Department of Energy, are to develop, demonstrate, and encourage the use of hydrothermal energy. This document outlines progress during the semiannual reporting period of October 1, 1980, to March 31, 1981.

Construction of the 5-MW Pilot Power Plant at the Raft River Geothermal Test Site is complete except for plant instrumentation. Facility turnover was completed in January 1981. Several plant modifications were made, and system operational testing was conducted.

In the Water Treatment Program, corrosion studies of carbon steel were completed; a phosphate-based corrosion inhibitor system was specified as acceptable and adequate to prevent plant shutdown caused by corrosion. Study results indicate that treatment of the water for silica and hardness reduction will be required for any geothermal water source to be used as cooling tower makeup. Alternative methods of removing silicas are being evaluated.

At the Prototype Power Plant, the first runs of the ORNL condenser tests were completed in October; a portion of these tests was repeated in December, and again in March. Checkout of the direct-contact heat exchanger (DC HX) was started in January. However, failure of a flexible piping hose and the cold weather postponed further testing until March. A report on the automatic run test flush with the shell and the tube boiler was published; two papers were prepared for presentation at the August 16th Intersociety Energy Conversion Engineering Conference IECEC)-"Performance and Operational Experiences of a Prototype Binary Geothermal Power Plant" and "Analysis of Mixed Hydrocarbon Binary Thermodynamic Cycles for Moderate Temperature Geothermal Resources." An informal report was published summarizing the analyses of a number of binary cycles using mixed hydrocarbon working fluids.

At the University of Utah, testing of the directcontact apparatus started. The numerical studies of shell and tube heat exchangers were completed, and a report is being prepared. A report on sieve tray direct-contact preheaters was completed.
Design was completed and construction started on an apparatus for performing direct-contact condensing studies.

Packed bed condenser studies continued; a theoretical study of condensation on a thin film of coolant flowing over a spherical packing was completed.

Objectives, scope, and approach were outlined for a task involving evaluation of potential advanced technologies for application in an advanced binary geothermal pilot plant. The task, initiated in February 1981, includes participation by Lawrence Berkeley Laboratory (LBL), Oak Ridge National Laboratory (ORNL), and Idaho National Engineering Laboratory (INEL).

Under the Reservoir Engineering Program, production-injection tests were conducted from Raft River Geothermal Exploratory Well No. 3 (RRGE-3) to Raft River Geothermal Injection Well No. 7 (RRGI-7); and from Raft River Geothermal Production Well No. 5 (RRGP-5) to RRGI-7. Results indicated no observable response in monitor wells from production or injection. Test details will be published in the Raft River Reservoir Engineering Semiannual Report. Planned reservoir tests and reports were cancelled because of pump failures.

The Low-Temperature Reservoir Engineering Program began in February. Handbook sections on testing and analysis methods and on available instrumentation, begun in February, are scheduled for review and editing in June.

Case studies of direct use of low-to-moderatetemperature resources, completed in March, are being reviewed for publication.

The Environmental Program continued at Raft River. The black-tailed jackrabbit population was censused in March to provide prey data for the raptor monitoring program. Research emphasized completing baseline studies on terrestrial fauna, monitoring air quality and meteorology, completing the fluorosis study, and monitoring water level changes in the shallow monitor wells in response to geothermal resource development. 
The Peerless line shaft pump was installed in RRGE-3; two additional line shaft pumps are scheduled for June and July delivery. Quickresponse first aid training was completed by four Facility Operations employees.

Two proposers signed cooperative agreements with DOE under the User-Coupled Confirmation Drilling Program-GeoProducts Corp. of Susanville, California, and the City of Alamosa, Colorado.

Costs of three aspects of direct use of hydrothermal energy were investigated-transmission, capital cost differential of industrial use equipment, and colocation of feedstock production and hydrothermal resources for ethanol plants. Capital cost differential evaluation was extended to nine additional industries projected to be the greatest hydrothermal users. The hydrothermal equipment was found significantly less expensive than conventional boilers.

Under the Marketing Assistance Program, eight exhibits were presented; the Fact Sheet series was expanded to include eight topics. Display activities will be limited for FY-81 because of DOE funding reductions. The program received 33 technical assistance requests and 137 requests for technical information. The state teams were increasingly able to handle technical assistance requests. Eliot Allen and Associates was selected to provide financial assistance to five communities for district heating systems under the Community Assistance effort. The HUD/DOE District Heating and Cooling Program solicited proposals from communities for feasibility studies. Awardees will be offered technical data, reports, and assistance by the DOE District Heating Product Team. The Industry Advisory Team has selected food industry organizations for initial presentations.

During this period, EG\&G provided program management and technical support for 12 demon- stration projects in the Program Opportunity Notice (PON) Program and 10 engineering and economic studies in the Program Research and Development Announcement (PRDA) Program.

EG\&G Idaho's accomplishments under the Geothermal Applications Development task for the M-X Renewable Energy Systems package involved project management, including task definition, planning, and coordination; and concept definition, including scenario for using geothermal energy, and development of generic parameters for power production and space conditioning. 


\section{CONTENTS}

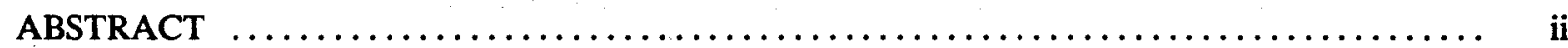

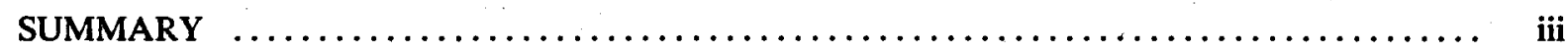

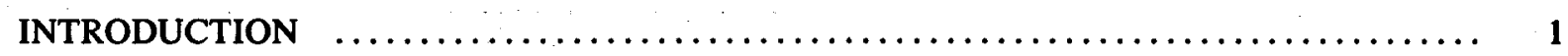

FIVE-MEGAWATT PILOT POWER PLANT $\quad \ldots \ldots \ldots \ldots \ldots \ldots \ldots \ldots \ldots \ldots \ldots \ldots \ldots \ldots$

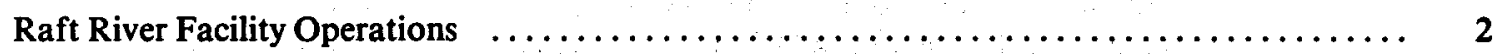

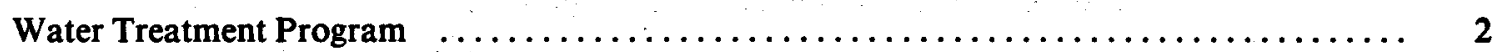

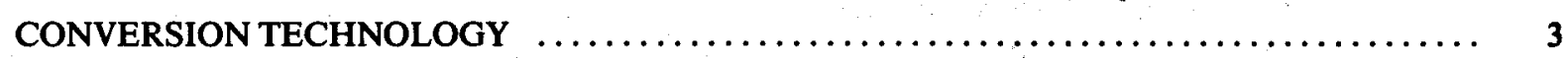

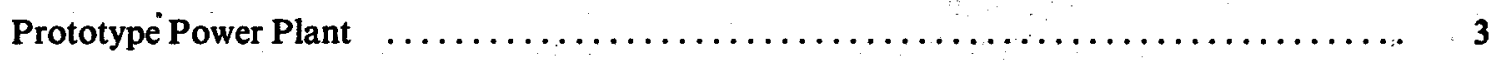

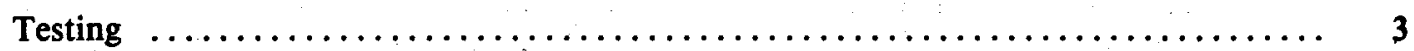

Mixed Hydrocarbon Working Fluid Analysis $\ldots \ldots \ldots \ldots \ldots \ldots \ldots \ldots \ldots \ldots, \quad 3$

Plant Modifications $\ldots \ldots \ldots \ldots \ldots \ldots \ldots \ldots \ldots \ldots \ldots \ldots \ldots \ldots, \quad 3$

Direct-Contact Heat Exchangers and Related Studies $\ldots \ldots \ldots \ldots \ldots \ldots \ldots \ldots \ldots \ldots \ldots \ldots$

Liquid-Liquid Direct-Contact Heat Exchanger Modification $\ldots \ldots \ldots \ldots \ldots \ldots \ldots \ldots, 4$

Studies of Primary Heat Exchangers with Augmentation $\ldots \ldots \ldots \ldots \ldots \ldots \ldots \ldots, 4$

Sieve Tray Column Studies $\ldots \ldots \ldots \ldots \ldots \ldots \ldots \ldots \ldots \ldots \ldots \ldots \ldots \ldots \ldots \ldots, \quad 4$

Multiple-Purpose Heat Transfer Apparatus $\ldots \ldots \ldots \ldots \ldots \ldots \ldots \ldots \ldots \ldots \ldots \ldots, 4$

Packed Bed Condenser Studies $\ldots \ldots \ldots \ldots \ldots \ldots \ldots \ldots \ldots \ldots \ldots \ldots \ldots, 4$

Advanced Conversion System $\ldots \ldots \ldots \ldots \ldots \ldots \ldots \ldots \ldots \ldots \ldots \ldots \ldots \ldots \ldots \ldots \ldots \ldots \ldots \ldots \ldots, \quad 4$

RAFT RIVER RESERVOIR ENGINEERING $\quad \ldots \ldots \ldots \ldots \ldots \ldots \ldots \ldots \ldots \ldots \ldots \ldots \ldots \ldots \ldots$

RAFT RIVER ENVIRONMENTAL PROGRAM $\ldots \ldots \ldots \ldots \ldots \ldots \ldots \ldots \ldots \ldots \ldots \ldots \ldots$

LOW-TEMPERATURE RESERVOIR ENGINEERING PROGRAM $\ldots \ldots \ldots \ldots \ldots \ldots \ldots \ldots$. 6

USER-COUPLED CONFIRMATION DRILLING PROGRAM $\ldots \ldots \ldots \ldots \ldots \ldots \ldots \ldots \ldots, 6$

GeoProducts Corporation, Susanville, California $\ldots \ldots \ldots \ldots \ldots \ldots \ldots \ldots \ldots \ldots \ldots \ldots$

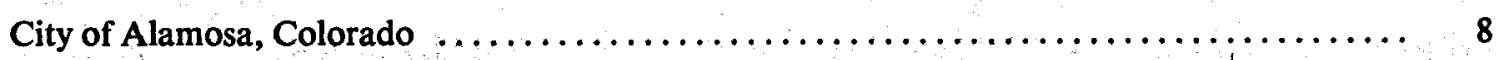

HYDROTHERMAL MARKET SHARE ESTIMATE $\ldots \ldots \ldots \ldots \ldots \ldots \ldots \ldots \ldots \ldots \ldots \ldots \ldots$

Hydrothermal Transmission Costs $\ldots \ldots \ldots \ldots \ldots \ldots \ldots \ldots \ldots \ldots \ldots \ldots \ldots \ldots \ldots \ldots \ldots \ldots \ldots \ldots \ldots, \quad 8$

Capital Cost Differential of Industrial Utilization Equipment $\ldots \ldots \ldots \ldots \ldots \ldots \ldots \ldots \ldots$

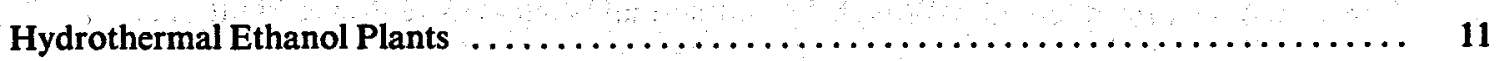

MARKETING ASSISTANCE PROGRAM $\quad \ldots \ldots \ldots \ldots \ldots \ldots \ldots \ldots \ldots \ldots \ldots \ldots \ldots \ldots \ldots \ldots \ldots$ 


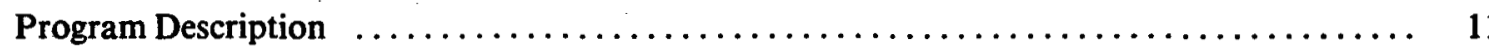

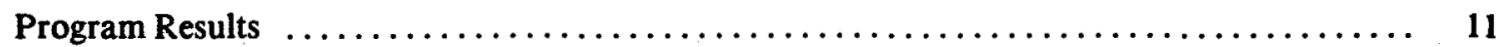

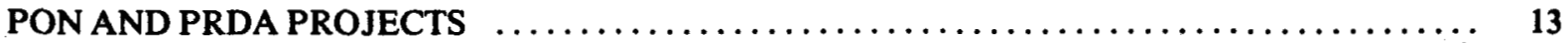

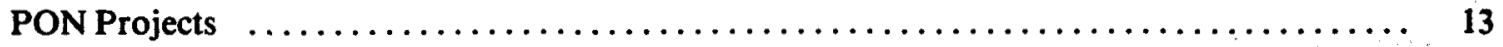

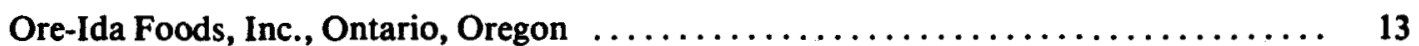

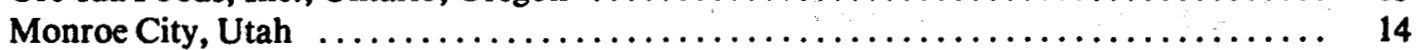

Haakon School District, Phillip, South Dakota $\ldots \ldots \ldots \ldots \ldots \ldots \ldots \ldots \ldots \ldots \ldots . . . \ldots \ldots$

St. Mary's Hospital, Pierre, South Dakota $\ldots \ldots \ldots \ldots \ldots \ldots \ldots \ldots \ldots \ldots \ldots \ldots \ldots$

Diamond Ring Ranch, Haakon County, South Dakota $\ldots \ldots \ldots \ldots \ldots \ldots \ldots \ldots . . \ldots \ldots$

Elko, Nevada .............................................. 15

Warm Springs State Hospital, Montana $\ldots \ldots \ldots \ldots \ldots \ldots \ldots \ldots \ldots \ldots \ldots \ldots \ldots \ldots \ldots$

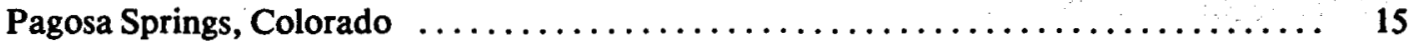

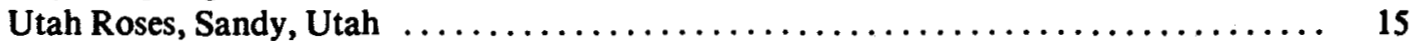

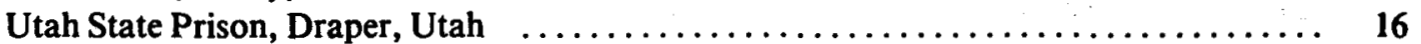

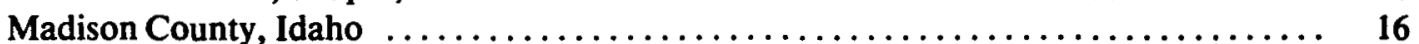

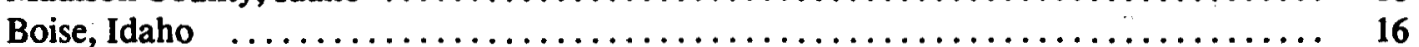

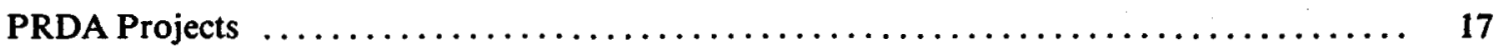

Direct Application of Geothermal Energy at the $\mathrm{L}^{\mathbf{3}}$ eggs Products Plant,

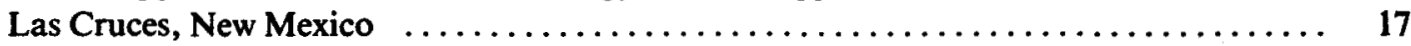

Direct Application of Geothermal Energy for Ethanol Production for

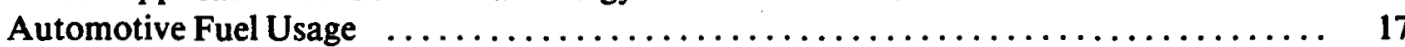

Evaluation of Direct Hot Water Geothermal Applications on the

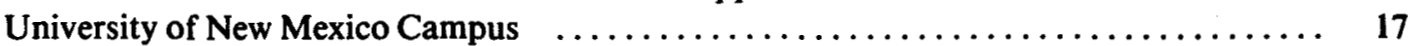

Municipal Geothermal Heat Utilization Plan for Glenwood Springs, Colorado . . . . . . 17

Geothermal Space Heating in Poplar, Montana ........................ 17

Engineering, Marketing, and Economic Study of a 4.5 Million-Gallon

Geothermal Fuel Alcohol Plant for the Vale Geopark Site $\ldots \ldots \ldots \ldots \ldots \ldots \ldots \ldots \quad 17$

Resource, Engineering, and Economic, Study for Direct Heat Applications of

Geothermal Energy at the Salida (Colorado) Geothermal Project $\ldots \ldots \ldots \ldots \ldots \ldots \ldots$

Commercial Production of Ethanol in the San Luis Valley, Colorado ............. 18

Resource, Engineering, and Economic Study for the Great Western Malting Co.

Geothermal Project $\ldots \ldots \ldots \ldots \ldots \ldots \ldots \ldots \ldots \ldots \ldots \ldots \ldots \ldots \ldots \ldots, 18$

Research and Development of Information on Geothermal Direct Heat

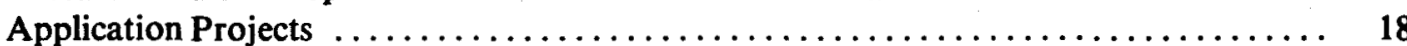

M-X/RES-GEOTHERMAL APPLICATIONS DEVELOPMENT $\ldots \ldots \ldots \ldots \ldots \ldots \ldots \ldots$

APPENDIX A-PUBLICATIONS OF THE IDAHO GEOTHERMAL PROGRAM $\ldots \ldots \ldots \ldots \quad 23$

\section{FIGURES}

1. Work flow of projects under the User-Coupled Confirmation Drilling Program $\ldots \ldots \ldots \ldots, 7$

2. Location of GeoProducts 55-MW Hybrid Geothermal Wood-Waste Power Plant $\ldots \ldots \ldots \ldots \quad 8$

3. Location of City of Alamosa, Colorado Project $\ldots \ldots \ldots \ldots \ldots \ldots \ldots \ldots \ldots \ldots \ldots \ldots \ldots$

4. Transmission costs of hydrothermal energy_capital cost per mile versus mass flow rate $\ldots \ldots \ldots 11$ 
5. Capital cost differential-conventional industrial boilers versus hydrothermal energy equipment for $176^{\circ} \mathrm{C}\left(350^{\circ} \mathrm{F}\right)$ geothermal fluid

.........

6. Net brine effectiveness-performance levels of conventional binary and dual-flash steam plants contrasted with those expected for advanced binary plants using fluids developed for $\mathbf{M}-\mathbf{X}$

7. Cycle schematic for $20-\mathrm{MW}(\mathrm{e})$ geothermal electric plant

\section{TABLES}

1. Cycle state points for a geothermal temperature of $204^{\circ} \mathrm{C}\left(400^{\circ} \mathrm{F}\right) \ldots \ldots \ldots \ldots \ldots \ldots \ldots$

A-1. EG\&G Idaho, Inc., formal reports of the Idaho Geothermal Program 


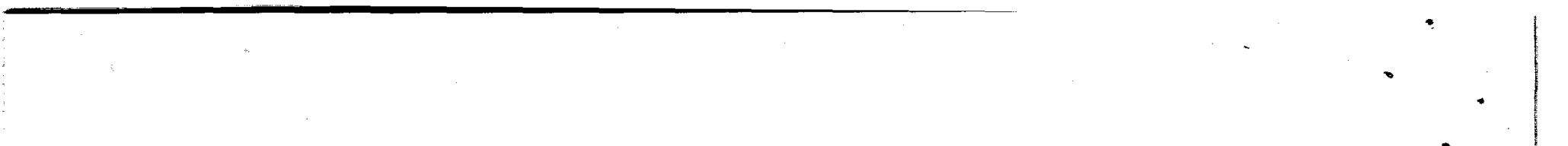

viii 


\section{SEMIANNUAL PROGRESS REPORT FOR THE IDAHO GEOTHERMAL PROGRAM}

\section{INTRODUCTION}

The Idaho Geothermal Program, sponsored by the Department of Energy (DOE), has conducted field experiments and demonstrations at the Raft River Geothermal Test Site since 1973. Located in south-central Idaho, this area is the center of wideranging studies into various uses of its mediumtemperature $\left(150^{\circ} \mathrm{C}\right)$ geothermal fluids. Activities there involve electric power generation, conversion technology (including research into direct-contact heat exchangers), various direct applications, studies of water treatment methods, reservoir engineering, and environmental protection.

Personnel from DOE's Idaho National Engineering Laboratory (INEL) perform experiments and support functions at Raft River and, from DOE's facilities in Idaho Falls, assist DOE in conducting studies and in monitoring and administering various other programs. Among these are programs for providing technical assistance and information to potential developers of geothermal energy resources. Progress of these activities is summarized in this report.

\section{FIVE-MEGAWATT PILOT POWER PLANT}

\section{(L. Walrath)}

The objective of this activity is to demonstrate the technical, economical, and environmental feasibility of using geothermal fluids with temperatures lower than $150^{\circ} \mathrm{C}$ to generate electric energy. The facility is a 5-MW(e) (gross power) pilot plant using standard state-of-the-art components and an organic Rankine cycle. The Program provides for all elements of management, engineering, testing, and operation of the plant.

Construction work has been completed except for plant instrumentation, which was partially completed at termination and settlement of the construction contract.

Warranty repairs continue to be processed. Facility turnover was completed in January 1981.

Several plant modifications were incorporated, including the following:

- Additional ladders, platforms, and catwalks
- Strainers on the suction side of the isobutane pumps

- Bypass cooling water return piping around the cooling tower.

- Additional heating capacity in the cooling water pumphouse, firewater pumphouse, and motor control center.

- Chemical storage building materials

- Design and installation of mechanical modifications in the water treatment system

- Piping design and corrections for cooling water to the vapor compressor cooler

- Flare heat shield design and installation

- Isolation of flare and air systems

- Overpressure protection of the domestic water system

- Electrical outlets for machine tools in the maintenance building

- Substitution of steel plates for flow sight glasses in the isobutane system

- Additional lightning protection over the process area

- Design and initiation of installation of electrical modifications for the water treatment system

- Initiation of grading and graveling around the process area

- Other minor modifications identified during system operational tests.

System operational testing included the following:

- Preparation of test documents for various component and system checks and operational tests

- Pressure test and hot flush of the geothermal system at $139 \mathrm{~L} / \mathrm{s}(2200 \mathrm{gpm})$ 
- Operational tests of fire protection systems

- Pneumatic pressure test and blowdown of the flare system

- Draining, cleaning, pneumatic pressure testing and isolation of the isobutane and propane storage tanks

- Domestic water system operation

- Pressure test and flush of the lube oil system for the turbine-generator (T-G)

- Static test of the T-G governor control system

- Passivation, leak testing, and isolation of the main condenser

- Removal, testing, and reinstallation of all system relief valves.

Operations and Maintenance activities included:

- Continuation of plant operator training and qualification in the operation of components, systems, fire protection, emergency action, and quick response first aid and safety.

- Overhaul of the plant air compressor

- Calibration of plant instrumentation

- Inspection of bearings for the turbine

- Routine plant maintenance.

\section{Raft River Facility Operations}

\section{(L. Walrath)}

The objective of this project is to provide general and systems maintenance functions for the 5-MW(e) power plant and associated support systems. Items covered include instrumentation calibration and maintenance, and electrical, and computer maintenance, and general site and systems maintenance. Warehousing, facility upkeep, and operational support of the Raft River well field and the power plant are provided in this account.

The Peerless line shaft pump that was removed from the Raft River Geothermal Production Well
No. 5 (RRGP-5) and renovated, has been installed in the Raft River Geothermal Exploratory Well No. 3 (RRGE-3). Systems operating tests were completed satisfactorily with factory representatives observing. Two additional line shaft pumps are on order, with delivery scheduled for June 19 and July 16, 1981. An 18-hour integrated well field test was successfully completed, pumping from RRGE-1, RRGE-3, and Raft River Geothermal Production Well No. 5 (RRGP-5) through the 5-MW(e) geothermal system and injecting into Raft River Geothermal Injection Well No. 6 (RRGI-6) and RRGI-7.

The REDA rental pump was removed from the RRGE-1 well and returned to the factory. A new "geothermally hardened" 680-hp down hole pump was installed in the RRGE-1. A long-term test from the RRGE-1 to the RRGI-7 was started using the new pump, which failed after 7 minutes of operation. The pump was pulled and returned to the manufacturer. Preliminary inspection revealed water in the lower motor and no oil in the upper motor.

The injection test from RRGP-5 to RRGI-7 was run for 92 hours, at which time the production pump failed. The test was continued from the RRGE-3 to the RRGI-7 for a total injection time of 238 hours. Data from this test were analyzed, and a report will be published in the Raft River Reservoir Engineering Semiannual Report.

Pipe racks have been constructed to support pump removal and installation work. A compressed gas cylinder storage rack and a loading dock were built in the storage yard, providing greater safety.

The quick-response first aid training has been completed. We now have four employees fully qualified as quick-response aides.

\section{Water Treatment Program}

\section{(D. Suciu)}

The purpose of the Water Treatment Program is to define the chemical requirements for each water treatment component of the 5-MW pilot power plant.

Corrosion studies of carbon steel were completed, and a phosphate-based corrosion inhibitor system was specified as being environmentally 
acceptable and adequate to prevent plant shutdown due to corrosion problems for more than two years.

The spinner test apparatus was used to evaluate the corrosion characteristics of alternative tubing material for the 5-MW pilot power plant. This best equipment is now being used to evaluate materials that may have application in other areas using spent geothermal brine as cooling tower makeup. A report of test results is being prepared.

The pilot cooling tower test units are being used to determine corrosion characteristics of alternative materials with heat transfer. These materials were selected on the basis of performance in the spinner tests. The tests will run for approximately 6 months to provide accurate longterm corrosion data of materials exposed to cooled, aerated geothermal brines.

Results to date indicate that the use of any geothermal water source as cooling tower makeup will require that the water be treated for silica and hardness reduction. Data show that lime softening is not economical. The program has been evaluating alternative methods of removing silicas, including the use of scrap iron, ion exchange resins, and the possible use of a sand bed in conjunction with ion exchange or iron for silica removal.

\section{CONVERSION TECHNOLOGY}

\section{(J. F. Whitbeck)}

\section{Prototype Power Plant (O. J. Demuth and G. Mines)}

Testing. The first runs of the ORNL condenser performance tests in the prototype power plant, using the shell and tube boiler/preheater as the vapor generator, were completed in October. Following these tests, the plant was prepared for winter operation with the direct contact heat exchanger. In December, a portion of the ORNL condenser performance tests was repeated using the shell and tube boiler since data taken during the first test indicated the unit at times was operating below expectations.

The direct-contact heat exchanger (DCHX) was started up, and checkout started in January. No major obstacles were encountered in the operation of the DCHX. However, the failure of a stainless steel flexible piping hose in the geothermal fluid system raised some questions regarding the safety of the remaining flexible hoses in the plant, several of which are in the isobutane system. This failure and the cold weather postponed further testing until March.

In March, the ORNL condenser tests were again partially repeated using the shell and tube boiler to see if the limited DCHX operation to date had adversely affected the condenser performance. During this period of testing, the maximum power output achieved with the plant thus far was obtained, $65 \mathrm{~kW}(\mathrm{e})$.

A report summarizing the automatic run test flush with the shell and the tube boiler (including the ORNL condenser) was published, and a paper titled "Performance and Operational Experiences of a Prototype Binary Geothermal Power Plant" was prepared for presentation at the 16th Intersociety Energy Conversion Engineering Conference (IECEC) in August 1981.

Mixed Hydrocarbon Working Fluid Analysis. Following completion of the analyses of a number of binary cycles using mixed hydrocarbon working fluids (as well as of several reference cycles) for geothermal resource temperatures of $138^{\circ} \mathrm{C}$ $\left(280^{\circ} \mathrm{F}\right)$ and $182^{\circ} \mathrm{C}\left(360^{\circ} \mathrm{F}\right)$, preparation of an informal summary report was completed in February 1981 (PG-G-80-041) and forwarded to DOE. A paper titled "Analyses of Mixed Hydrocarbon Binary Thermodynamic Cycles for Moderate Temperature Geothermal Resources" was prepared for presentation at the 16th IECEC in August 1981.

Plant Modifications. Design of heat exchangers for the vaporization and condensation of a $90 \%$ propane, $10 \%$ isopentane working fluid is in progress. These units will be used in experiments on supercritical mixed hydrocarbon binary cycles to investigate the substantial potential gains in the effectiveness of geofluid use predicted by cycle analyses. A preliminary design effort was initiated to modify the Prototype Power Plant so as to accommodate the new vapor-generating system.

To eliminate the introduction of noncondensable gases into the working fluid system when working fluid is added to the plant, a small charging system was built and installed. In addition, a new storage and charging station was designed, 
and construction of the station was started. This new station will be used to add the two different working fluid components for the working fluid mixture tests.

\section{Direct-Contact Heat Exchangers and Related Studies}

(R. F. Boehm and H. R. Jacobs, University of Utah)

Most items pursued during this reporting period are continuations of topics discussed in the previous semiannual report. For this reason, extensive introductions to the topics will not be given here. All projects noted here have been carried out on a no-cost extension while a continuation contract is being drawn up.

Liquid-Liquid Direct-Contact Heat Exchanger Modification. The modification to the directcontact apparatus noted in the previous report was completed, and testing was started. This device incorporates an insulated glass test section to facilitate visual studies. Although detailed studies of the design of both fluid injectors (water as the continuous phase and kerosene as the dispersed phase are being used currently) are not yet complete, preliminary studies have given great insight to the importance of the design of these components. In fact, the initial design of the water injector was found to have a significantly negative effect on the tower performance at higher flows. Redesign boosted performance by nearly $30 \%$.

Studies of Primary Heat Exchangers with Augmentation. These numerical studies of shell and tube heat exchangers using finned surfaces have now been completed. A summary report is being prepared. As noted previously, some augmented tube designs (particularly designs with longer fins) show extremely cost-effective performance over that of smooth tube designs. The largest uncertainties relate to a paucity of design data for tubes with fins that have large length-to-width ratios.

Sieve Tray Column Studies. A report on sieve tray direct-contact preheaters was completed. A model was developed that predicts the temperature profile between trays to within $5 \%$. The experimental work on sieve trays showed that at least a $15 \%$ increase in heat transfer is possible over that achievable with a spray column tray preheater.
Multiple-Purpose Heat Transfer Apparatus. The design of an apparatus for performing directcontact condensing studies has been completed, and construction is well along. Initially, the device will be used to study collapsing bubble condensation in direct contact. Pentane vapor flowing upward will be condensed by water flowing downward. The test vessel has a flow cross-section area of slightly less than $0.75 \mathrm{~m}^{2}\left(8 \mathrm{ft}^{2}\right)$.

Packed Bed Condenser Studies. Packed bed condenser studies have continued during this reporting period. A theoretical study of condensation on a thin film of coolant flowing over a spherical packing was completed. The model was compared with experimental data from the literature (A. Tamir, and I. Rachmilev, International Journal of Heat and Mass Transfer, Vol. 17, pp. 1241-1251, 1974; and Y. Finklestein, and A. Tamir, The Chemical Engineering Journal, Vol. 12, pp. 199-209, 1976. Good agreement was found.

Models are currently being developed to assess the effects of noncondensables on condenser performance. This work has been delayed while the continuation funding is being negotiated.

\section{Advanced Conversion System}

\section{(J. F. Whitbeck and O. J. Demuth)}

A task initiated in February 1981 is concerned primarily with evaluating various advanced technologies for possible application in an advanced binary geothermal pilot plant. An outline defining the objectives, scope, and approach to the task, which includes participation by LBL, ORNL, and INEL, was drafted and sent to DOE, LBL, and ORNL for review and comment. Initial cases planned for evaluation include cycles with isobutane (as a reference), isobutane/isopentane, and propane/isopentane working fluids using a $182^{\circ} \mathrm{C}\left(360^{\circ} \mathrm{F}\right)$ resource that has pumped production wells. Shell and tube cycles with most cooling towers will be evaluated first.

\section{RAFT RIVER RESERVOIR ENGINEERING}

\section{(S. G. Spencer)}

Analysis of the testing of RRGE-1 at high rates, which was completed September 10, 1980, has 
been written up. New estimates of the productivity of RRGE-1 will be made using the results of these analyses. A planned high-rate test with production from RRGE-1 and injection into RRGI-7 was cancelled because of failure of the pump at RRGE-1. A production-injection test from RRGE-3 to RRGI-7 was conducted between March 20 and March 30 at a rate of $44 \mathrm{~L} / \mathrm{s}$ (700 gpm). A 96-hour production-injection test from RRGP-5 to RRGI-7 was also conducted in March. The purpose of the test was to determine the response of monitor wells to production at RRGE-3 and injection into RRGI-7. The preliminary analysis of data indicates that neither production nor injection produced an observable response in any monitor wells. The results of test analyses will be published in more detail as part of the Raft River Reservoir Engineering Semiannual Report.

Response of the monitor well system to production-injection testing at RRGE-3, RRGI-6, and RRGI-7 was studied using data from earlier tests. Definite response to RRGI-6 injection was observed in Monitor Well No. 4 (MW-4). A report on the monitor well system will be published as part of the Raft River Reservoir Engineering Semiannual Report.

The LBL ANALYZE well test analysis code has been debugged and is being tested for use in analyzing the most recent production-injection (RRGE-3 to RRGI-7) test data.

Because of repeated pump failures, scheduled reservoir tests have been repeatedly cancelled. As a result, planned reports have been delayed or cannot be prepared because data are lacking. The major barrier to adequate reservoir testing at Raft River is the lack of a reliable pump.

\section{RAFT RIVER ENVIRONMENTAL PROGRAM}

\section{(S. G. Spencer)}

The Raft River Environmental Program is designed to assess the beneficial and detrimental impacts to the environment resulting from development of a moderate-temperature geothermal resource. Research during the reporting period emphasized completing baseline studies on terrestrial fauna, monitoring air quality and meteorology, completing the fluorosis study, and studying water level changes in the shallow monitor wells in response to development of the geothermal resource.

The effects of production-injection testing on the monitor wells are summarized in the reservoir engineering section of this report. A detailed discussion can be found in the Groundwater. Monitoring Program Progress Report (to be released). Water from the monitor wells was sampled in December and again in March. Rather than using downhole samplers, a portable submersible pump was borrowed from the Idaho Department of Water Resources, and the monitor wells were extensively pumped to clean out the well bore before samples were taken. Chemical analyses of these samples are complete, except for sodium.

The seismic network consists of three stations in the Raft River Valley recording microseismic events. The data are comparable to data recorded at other seismograph stations, confirming that the Raft River array is operational. Six earthquakes located within $6 \mathrm{~km}(3.7 \mathrm{mi})$ of the seismograph array were recorded during this reporting period. They occurred during an 8-hour period, and all were less than 0.5 on the Richter scale. The seismograms from this sequence of events were similar, indicating that the source mechanism and propagation paths were the same. Otherwise, no microseismic events were recorded within $40 \mathrm{~km}$ $(25 \mathrm{mi})$ of the Raft River array.

The weather station east of RRGE-2 continually monitors wind velocity and direction, precipitation, ambient air temperature, and dew point temperature. Modifications in the software appear to have corrected most of the problems in the data transmission and receiving system. Precipitation during the reporting period was unusually low, except during the month of January.

The air quality monitoring program is designed to collect baseline data and to identify the impacts of suspended particulates released due to geothermal development. Four stations have been operated in the Raft River Valley since the beginning of this reporting period, sampling every 6 days for a 24-hour period. The total suspended particulate (TSP) concentrations are correlated with hourly average wind histories during the sample day to identify sources of particulates. Background particulates are generated primarily by construction, farming, and vehicular traffic at 
or near the geothermal site. The highest particulate levels are observed at the station nearest to the unpaved access road to the site. The lowest levels are found at the station where the vehicular traffic is at a minimum. Particulate concentrations are related to windspeed and direction, being higher on windy days, particularly when the wind is from the direction of an unpaved road. All TSP concentrations are well below the maximum levels allowed under the primary and secondary National Ambient Air Quality Standards. Chromate concentrations have been undetectable $\left[<0.01 \mu \mathrm{g} / \mathrm{m}^{3}(<1 \mathrm{ppt})\right]$.

The black-tailed jackrabbit population was censused in March to provide prey data for the raptor monitoring program. The rabbit population has continued to decline from the peak years of 1978 and 1979. In March, the density of the black-tailed jackrabbit population was estimated to be approximately $300 / \mathrm{km}^{2}\left(116 / \mathrm{mi}^{2}\right)$ during the peak years. These data are essential for an accurate assessment of raptor population trends. The nesting success of the raptor population will continue to be assessed.

The fluorosis study was completed during this reporting period. Results of water sample analyses indicate that there is not enough fluoride in the drinking water to induce the high incidence of dental anomalies in the Raft River Valley. The cause of this anomaly remains unknown. The children are not receiving detrimental amounts of fluoride from the drinking water supplies, homegrown vegetables, home-produced milk, or irrigation water, and incidences of fluorosis are not correlated with residence time in the Valley. Further study may be warranted.

\section{LOW-TEMPERATURE RESERVOIR ENGINEERING PROGRAM}

\section{(S. G. Spencer)}

The objective of this program is to ensure that appropriate methods of reservoir testing and analysis are available to facilitate the development and use of low-to-moderate temperature hydrothermal resources by private industry.
The program was begun in February, and therefore this report covers only two months. Work on a handbook of well testing and analysis methods for low-to-moderate temperature geothermal wells is underway. The sections dealing with testing and analysis methodology and available instrumentation were begun during February and are scheduled for review and editing at the beginning of June. These sections will discuss testing and analysis methods available from the groundwater and petroleum industry that are applicable to use in hydrothermal reservoirs.

A group of case studies involving direct use of low-to-moderate-temperature resources was completed in March and is in the process of being reviewed for publication. The case studies to be published will include:

1. St. Mary's Hospital-Madison Formation

2. Susanville-volcanic

3. Pagosa Springs-Leadville Formation

4. Elko-Basin and Range

5. Monroe-fault controlled

6. Rexburg-volcanic.

The LBL ANALYZE model for multiple-well test analysis will be tested using Raft River well test data and used for analyzing data in this program. Predictions of reservoir behavior will be made using the USGS single-phase geothermal reservoir simulation code. These predictions will then be compared to data as they are accumulated during production. The results of these efforts will be published as a report on methods for analysis of production data from fields in hydrothermal reservoirs.

\section{USER-COUPLED \\ CONFIRMATION DRILLING PROGRAM}

\section{(M. R. Dolenc and J. A. Strawn)}

In response to an industry survey, DOE initiated the User-Coupled Confirmation Drilling 
Program (UCCDP) in 1980. The program was designed to absorb some of the risk and costs of exploring, drilling, and testing hydrothermal wells, while developing an infrastructure in the private sector, by cost-sharing the exploration through testing phase of direct-heat hydrothermal projects (see Figure 1). The DOE cost share is determined by a negotiated formula between DOE and the participant and ranges from $20 \%$ (for a completely successful well) to $90 \%$ (for a completely unsuccessful well).

In the UCCDP, EG\&G efforts were concentrated on technical evaluations for DOE negotiation and on technical support to DOE in the negotiation process. As was noted in the last semiannual report, eight projects were selected for negotiations in this program.
Two of the proposers, GeoProducts Corporation and the City of Alamosa, have signed cooperative agreements with DOE for their projects. The other firms are still in some phase of negotiation with DOE at this time.

\section{GeoProducts Corporation, Susanville, California}

GeoProducts Corporation plans to dehydrate wood residues and preheat boiler feedwater in a 55-MW hybrid geothermal wood-waste power plant at a location 30.6 kilometers (19 miles) east of Susanville, California. Under the UCCDP cooperative agreement, plans are to drill a 5,000 -foot well in an attempt to obtain a $149^{\circ} \mathrm{C}$ $\left(300^{\circ} \mathrm{F}\right)$ resource flowing at least $44 \mathrm{~L} / \mathrm{s}$

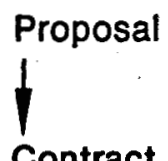

Contract with DOE

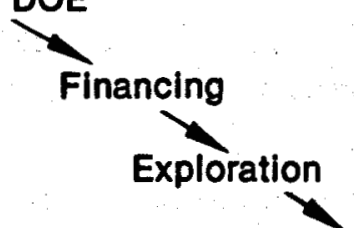

Drill site selection

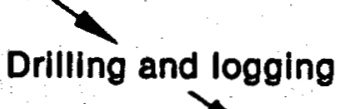

Flow testing

Injection well

Degree of success

DOE pays cost-share

Construction or retrofit

1

Energy use

INEL-A-18 773

Figure 1. Work flow of projects under the User-Coupled Confirmation Drilling Program. 
$(700 \mathrm{gpm})$. Figure 2 shows the location of the project in northeastern California's Lassen County.

Honey Lake Valley is a graben structure in the northwestern Basin and Range physiographic province. In the graben, Pliocene andesite flows and layered pyroclastic rocks are overlain by Pleistocene to recent lacustrine, aeolian sand, and alluvial fan sediments. Wendel and Amedee Hot Springs border the northeast side of the graben. Geothermometry suggests temperatures from 143 to $153^{\circ} \mathrm{C}$ (290 to $\left.307^{\circ} \mathrm{F}\right)$, depending on assumptions made on the mixing model. The two hot springs currently flow $96^{\circ} \mathrm{C}\left(205^{\circ} \mathrm{F}\right)$ fluid.

\section{City of Alamosa, Colorado}

The City of Alamosa hopes to find a $93^{\circ} \mathrm{C}$ $\left(200^{\circ} \mathrm{F}\right)$ resource flowing at least $44 \mathrm{~L} / \mathrm{s}(700 \mathrm{gpm})$ for use in a barley malting plant. A secondary use will be to provide space heating for Adams State College. Plans are to drill a 2286-meter (7,500-foot) well on city property to obtain the resource. This project is located in the San Luis Valley of southern Colorado (see Figure 3).

The San Luis Valley lies at the northern extreme of the Rio Grande Rift. This valley is a deep graben feature characterized by unconsolidated sands, silts, and clays, interbedded by volcanic flows. Volcanic material becomes scarce or absent in the upper strata. Shallow wells and hot springs in the valley, some of which are remote from Alamosa, have surface temperatures from 38 to $60^{\circ} \mathrm{C}\left(100\right.$ to $\left.140^{\circ} \mathrm{F}\right)$.

\section{HYDROTHERMAL MARKET SHARE ESTIMATE}

\section{(T. W. Lawford)}

The overall goals of the project are to provide realistic estimates of the overall national use of hydrothermal energy in the year 2000 and also to evaluate the federal programs aimed at accelerating the exploitation of this resource.

The results of Phase I of this study were outlined in the last report period. Phase II, with the objective of refining the Phase I results, was initiated during this report period. EG\&G investigated three aspects of the direct employment of hydrothermal energy, as outlined below.

\section{Hydrothermal Transmission Costs}

The capital and operation and maintenance costs of transmitting hydrothermal energy from a production location (well field) to the ultimate user(s) were developed. When combined with the costs of producing the geothermal fluid and compared with regional costs of competing energy sources, these data will allow determination of economic distances between the ultimate user(s) and geothermal production fields. Costs were developed for both single-pipe (fluid disposal near the user location) and dual-pipe (reinjection near the production field) systems. The study evaluated costs of systems handling up to $900 \times 10^{6} \mathrm{Btu} / \mathrm{hr}$. Figure 4 is representative of the series of curves developed.

\section{Capital Cost Differential of Industrial Utilization Equipment}

In order to realistically assess the true cost of hydrothermal energy to industrial users, it is necessary to evaluate the capital cost differential between conventional industrial boilers and the equipment necessary to use hydrothermal energy. The Phase I study applied the equipment capital cost differentials developed for three industries to all industrial users. For the Phase II study, this evaluation was extended to nine additional industries projected to be the greatest hydrothermal users in the Phase I study. These industries are: lumber drying, concrete block, synthetic rubber, pharmaceutical preparations, cheese/whey, greenhouses, soybean mills, dehydrated fruits and vegetables, and ethanol production. In all cases, the equipment needed for hydrothermal energy was found to be significantly less expensive than conventional boilers and associated equipment. Furthermore, the hydrothermal equipment showed significantly greater capital cost savings in the higher energy use range (greater than $32 \times 10^{6}$ $\mathrm{Btu} / \mathrm{hr}$ ) where coal-fired boilers are typically used. Figure 5 illustrates the equipment capital cost differential for a geothermal temperature of $177^{\circ} \mathrm{C}$ $\left(350^{\circ} \mathrm{F}\right)$. 


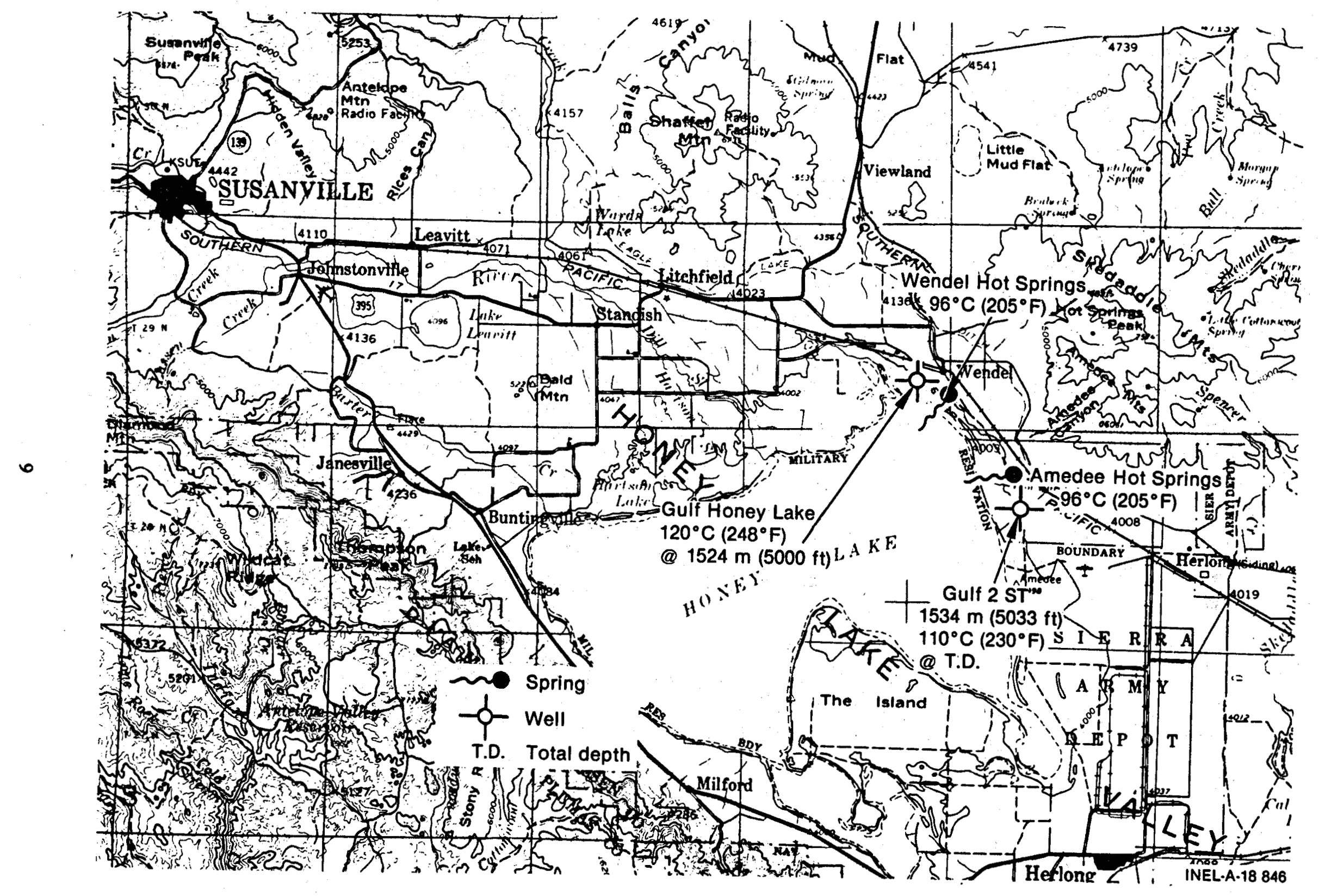

Figure 2. Location of GeoProducts 55-MW Hybrid Geothermal Wood-Waste Power Plant. 


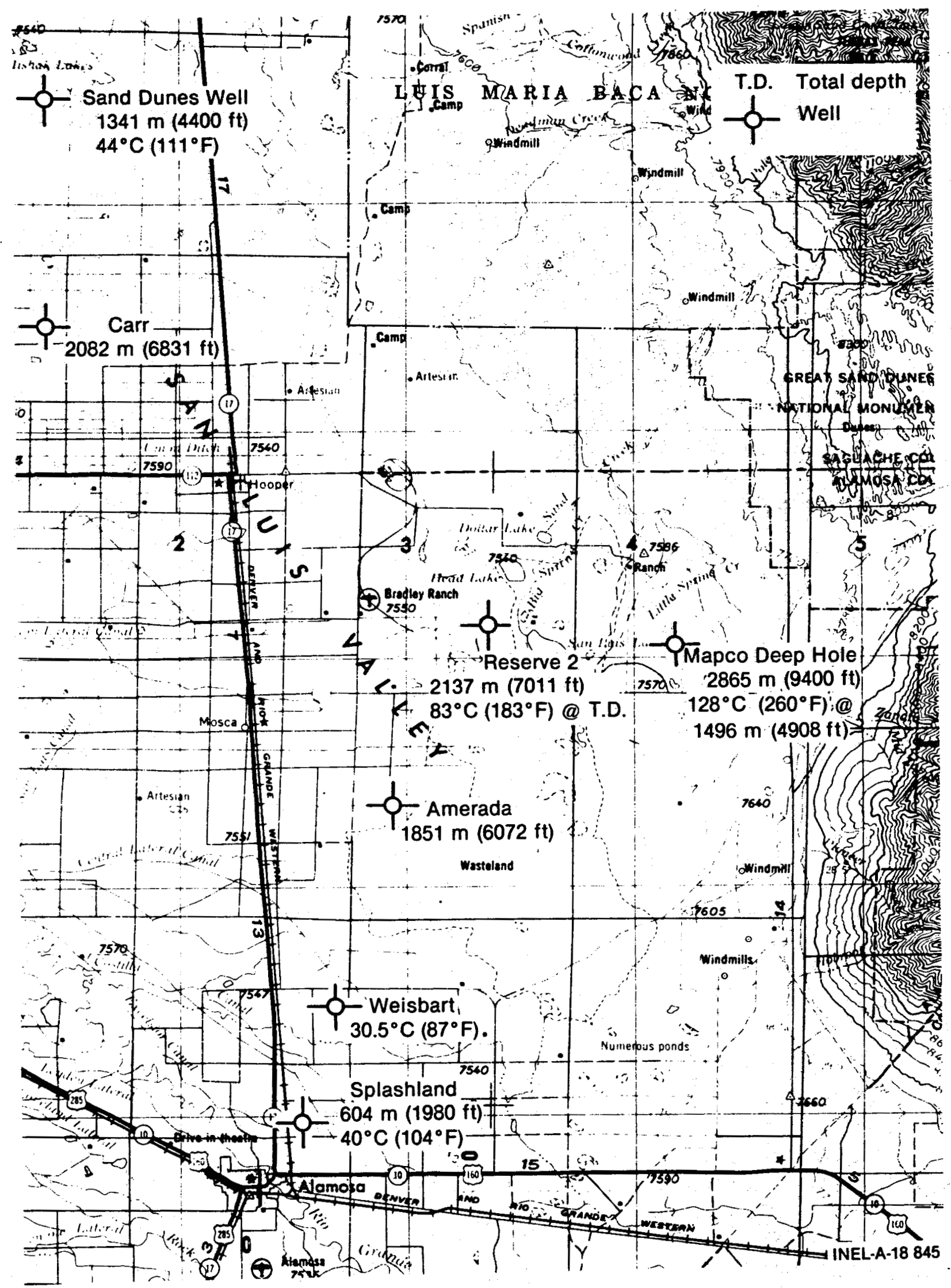

Figure 3. Location of City of Alamosa, Colorado Project. 


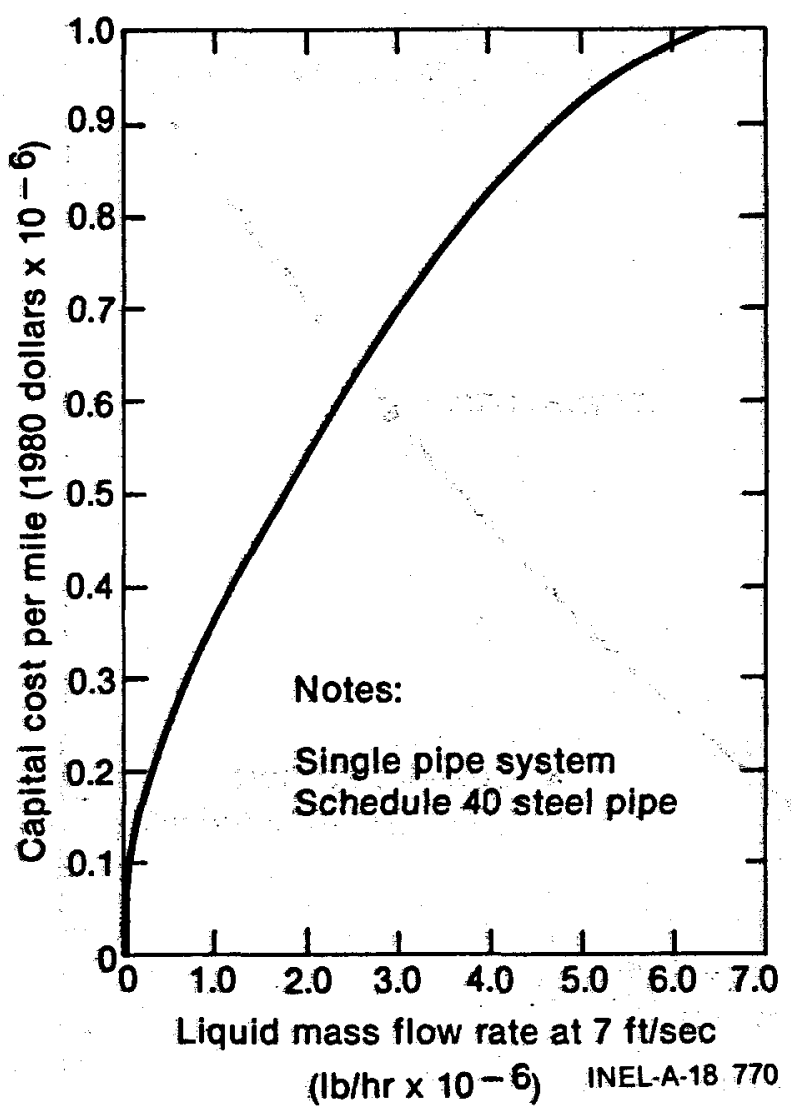

Figure 4. Transmission costs of hydrothermal energy-capital cost per mile versus mass flow rate.

\section{Hydrothermal Ethanol Plants}

Because the Phase I study predicted that large quantities of hydrothermal energy would be used by ethanol plants, a closer look is being taken at the colocation of feedstock production and hydrothermal resources. Data for this task are still being assembled at the end of this reporting period.

\section{MARKETING ASSISTANCE PROGRAM}

(W. J. Toth, I. A. Engen, and

F. L. Meltzer)

\section{Program Description}

Under DOE direction, EG\&G Idaho provides technical information and assistance to anyone interested in the direct application of geothermal energy. Information is provided to the public, pri- vate, and technical sectors through exhibits, displays, and presentations at conferences and meetings and through the distribution of pamphlets, brochures, and fact sheets. Technical assistance is provided to requesters in the Rocky Mountain Basin and Range Region through in-house engineers or through subcontracts to architectural and engineering firms. Up to 100 man-hours of assistance are available on a first-come, staff-available basis. By assisting requesters with technical information and initial feasibility determinations, users are encouraged to explore the development of geothermal resources further and to continue their efforts toward the eventual replacement of fossil fuels by geothermal energy.

The Marketing Assistance Program also includes other specialized efforts that are directed at particular sectors of the energy-consuming public. In the Community Assistance effort, communities with potential for geothermal district heating are provided with information on public and private funding sources and with assistance in applying for funding from these sources. In the District Heating Product Team effort, EG\&G will participate with other DOE contractors to provide specialized technical assistance to communities selected under the HUD/DOE District Heating and Cooling Solicitation. Through the Industry Advisory Team activities, which are coordinated by EG\&G Idaho, selected industrial sectors such as the food industries are provided with technical information, displays and exhibits, technical papers at industry conferences, workshops, short courses, seminars, and technical assistance in order to increase awareness that geothermal energy can be used to provide process heat. Through this program, potential users of geothermal energy are informed and assisted in their initial efforts to develop and use geothermal resources.

\section{Program Results}

Extensive efforts to disseminate information were made early in the reporting period, and these activities continued at a reduced level throughout the period. Eight exhibits were presented; more than 200,000 people were able to view the display materials and discuss geothermal energy with EG\&G personnel. The Geothermal Fact Sheet series now contains eight titles. In addition to the original three topics, there are now two fact sheets 


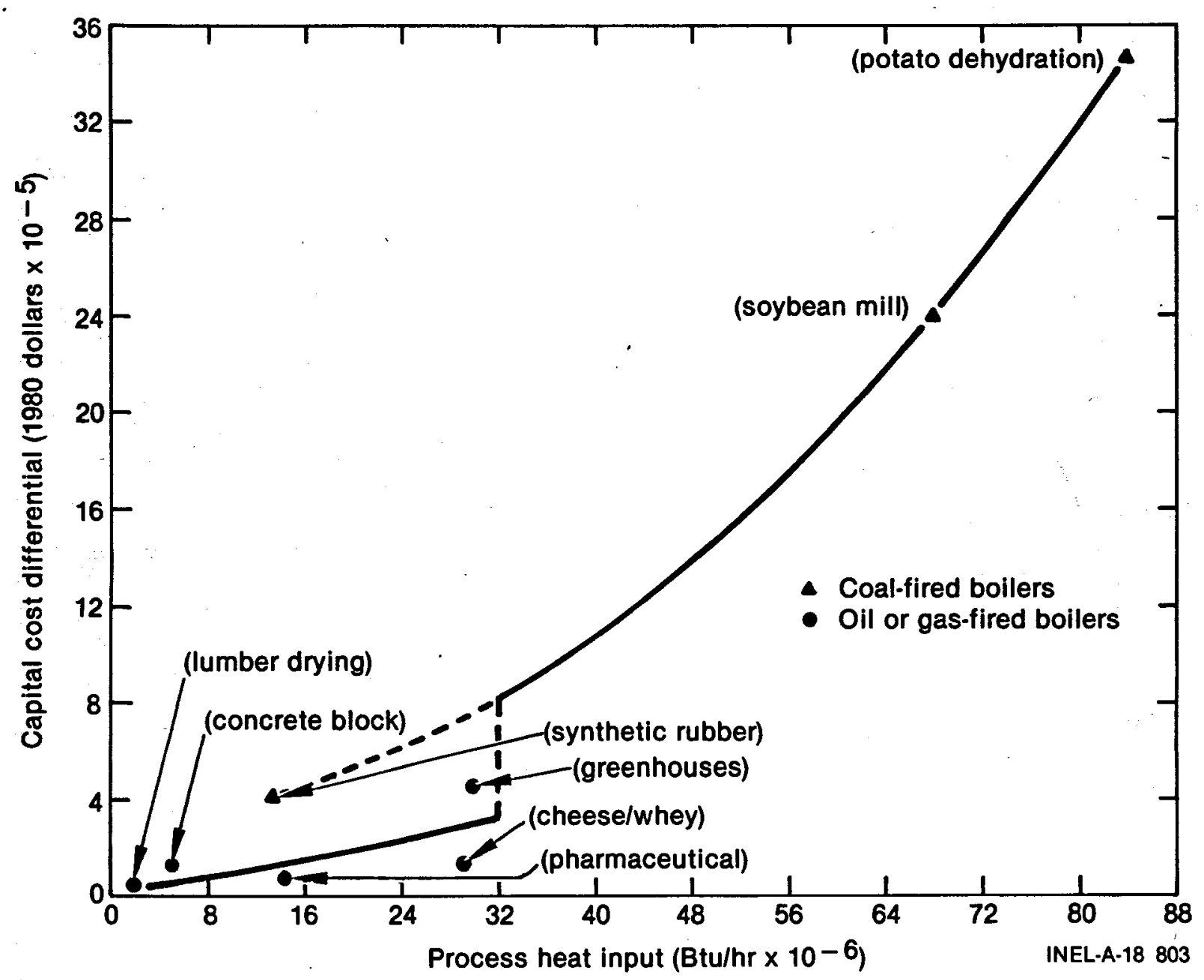

Figure 5. Capital cost differential-conventional industrial boilers versus hydrothermal energy equipment for $176^{\circ} \mathrm{C}$ $\left(350^{\circ} \mathrm{F}\right)$ geothermal fluid.

on various aspects of DOE's cost-shared PON (Program Opportunity Notice) projects, and individual fact sheets on resource availability, geothermal ethanol plants, and location and capacity of existing and proposed geothermal electrical plants. With DOE funding reductions, display activities will be limited for the remainder of FY-1981. Minor upgrading of exhibits will ready them for FY-1982 showings by EG\&G and for loan to state agencies for local showings.

Thirty-three requests for technical assistance and 137 requests for technical information were received during the reporting period. Nineteen technical assistance efforts were completed, and four efforts are subcontracted (one in Idaho, two in South Dakota, and one in New Mexico). During the second half of the fiscal year, increased subcontracting activity and additional available manpower will reduce the number of outstanding technical assistance requests, now at about 30 .
Coordination of technical assistance and subcontracting with state commercialization teams has apparently resulted in fewer technical assistance requests to EG\&G; the state teams are increasingly able to respond to a number of the requestors satisfactorily.

Representative projects receiving technical assistance in this reporting period include:

- The effect of well cost and heat load on the feasibility of using water-source heat pump equipment for space heating for the New York State Energy Research and Development Authority (NYSERDA)

- Space heating for a resort complex at Sula, Montana

- Primary heat exchanger evaluation for the hospital in White Sulfur Springs, Montana 
- Reservoir engineering advice and technical assistance to requestors in Mitchell, South Dakota; Boise, Idaho; Malad, Idaho; and Bozeman, Montana

- Condominium-spa development at Truth or Consequences, New Mexico

- Greenhouse development at Abraham Hot Springs, Utah

- A potential ethanol production plant in the Hells Canyon area of western Idaho.

Under the Community Assistance effort, Eliot Allen and Associates, Inc., has been selected to provide information and assistance to communities needing financial assistance with district heating systems. Initially, ten communities will be selected in the eight Rocky Mountain Basin and Range states for initial presentations. Based on their response, about five of these communities will be selected for more intensive assistance. Related to this effort is the HUD/DOE District Heating and Cooling Program, which solicited proposals from communities to perform initial feasibility studies. For the awardees of this program, DOE has formed a District Heating Product Team, which is composed of representatives from Technical Assistance Centers such as EG\&G, from other DOE contractors, and from various other interested parties. Technical data, reports, and assistance will be offered to the awardees by the team members.

The Industry Advisory Team has been formed to assist the industrial sectors in investigating the application of geothermal energy to their process heat requirements. Initially, the food industries have been selected for immediate attention. A bibliography of reports and data has been prepared. Food industry organizations have been contacted for information on meetings and conferences at which presentations can be made. One presentation has been given to a frozen and canned foods group in California, and at least one invitation has been accepted for future presentations.

The results of this multifaceted approach to geothermal energy development have been encouraging, as evidenced by the large number of contacts indicated above. The Marketing Assistance Program is proving to be a very effective method of presenting geothermal energy as a viable alternative to fossil fuels.

\section{PON AND PRDA PROJECTS}

\section{(F. Childs, L. Nelson, and J. Strawn)}

The EG\&G Idaho Geothermal Program Office provides technical assistance to DOE for the Program Research and Development Announcement (PRDA) Program and the Program Opportunity Notice (PON) Program. Both programs were instituted to assist the development of the direct application of geothermal energy. The PRDA Program consists of a series of studies designed to investigate the engineering and economic feasibility of geothermal direct applications. The PON Program is a demonstration project program in which project costs are shared between DOE and the private companies, municipalities, or organizations that are conducting the demonstrations. During this reporting period, EG\&G Idaho provided program management and technical support for 12 demonstration projects and nine engineering and economic studies. Each project is summarized below.

\section{PON Projects}

Ore-Ida Foods, Inc., Ontario, Oregon. The Ore-Ida Foods, Inc., plant at Ontario, Oregon, currently uses natural gas and oil, This project would substitute geothermal energy to provide potato processing heat, space heat, and hot potable water in the amount of about $97,200 \mathrm{MWh} / \mathrm{yr}\left(33.2 \times 10^{10} \mathrm{Btu} / \mathrm{yr}\right)$. Production was predicted to be $50 \mathrm{~L} / \mathrm{s}(800 \mathrm{gpm})$ at $160^{\circ} \mathrm{C}$ $\left(320^{\circ} \mathrm{F}\right)$ from two production wells. Two production wells and one injection well were planned.

The initial production well was drilled beyond its target depth of $2134 \mathrm{~m}(7000 \mathrm{ft})$ to a total depth of $3065 \mathrm{~m}$ (10,054 ft). Bottom hole temperature was $182^{\circ} \mathrm{C}\left(360^{\circ} \mathrm{F}\right)$, but flow was inadequate-only about $0.82 \mathrm{~L} / \mathrm{s}(13 \mathrm{gpm})$ with a water level at $1525 \mathrm{~m}$ ( $5000 \mathrm{ft}$ ). No additional drilling is planned. Crossplots of digitized electric log data showed that no porous zones were missed in the perforating program.

Planning and coordination between CH2M Hill, Los Alamos National Laboratory, EG\&G Idaho, and Ore-Ida is continuing. Current plans call for a formation breakdown test in preparation for either plugging and abandoning or additional fracturing of the Ore-Ida No. 1 well. 
Monroe City, Utah. The project planned to drill one production and one injection well, and to install a core district heating system core that could later be expanded to include the major areas of Monroe.

The production well obtained $75^{\circ} \mathrm{C}\left(165^{\circ} \mathrm{F}\right)$ at $38 \mathrm{~L} / \mathrm{s}(600 \mathrm{gpm})$, but this was only $43 \%$ of its expected capability. In addition, at the preliminary design stage, Monroe City's engineering consultants forecast a $100 \%$ project cost overrun, and predicted that revenues from the smaller resource might not cover operating costs. Recent reviews by Energy Services, Inc. and EG\&G Idaho estimated 10 to $40 \%$ cost overruns, but revenues were still marginal.

Since Monroe City is incapable of increasing its financial support and neither is DOE, Monroe City was asked to seek an economic alternative use for the resource. No alternative use has been proposed, and so DOE-ID plans to allow the cooperative agreement to expire. It is hoped that Monroe City will eventually find a customer for this potentially useful well.

Haakon School District, Philip, South Dakota. The project has been expanded in scope to include the space heating of the school complex and eight business buildings on the discharge line route. The Environmental Protection Agency required that the Ra-226 levels in the well water be reduced to $5 \mathrm{pCi} / \mathrm{L}$ prior to discharge to the $\mathrm{Bad}$ River. The project scope was expanded to include a water treatment facility. The water is being treated by injecting a $10 \%$ aqueous solution of barium chloride into the geothermal effluent. After a holding pond settling time of $\mathbf{4 8}$ hours, the water is discharged into the river. Approximately 2000 barrels of fuel oil will be replaced yearly, resulting in a payback of approximately 14 years.

The pipeline installation and building retrofit were completed, and the school system then went on-line for the 1980-81 heating season. A ribboncutting ceremony and dedication was held on October 24, 1980. The monitoring phase is in progress.

Periodic clogging of the static mixer is being caused by barium sulfide, which precipitates from the sulfide-rich water being used in the aqueous solution. EG\&G Idaho plans to field test a pilot model of a system using a contained barium sulfide bed to remove the Ra 226.
St. Mary's Hospital, Pierre, South Dakota. This project demonstrates the feasibility of using low-temperature water from a $665-\mathrm{m}$ (2181-ft) well in the Madison Aquifer for space, domestic hot water, and ventilation air heating. The well flows at a rate of $24 \mathrm{~L} / \mathrm{s}(375 \mathrm{gpm})$, at a temperature of $41^{\circ} \mathrm{C}\left(106^{\circ} \mathrm{F}\right)$, and at $186 \mathrm{kPa}$ (27 psig) residual pressure. The water from the well has $2084 \mathrm{ppm}$ total dissolved solids, a hydrogen sulfide content of $0.7 \mathrm{ppm}$, and an Ra-226 level of $19 \mathrm{pCi} / \mathrm{L}$. The well water is discharged through a PVC pipe to the Missouri River. The underground piping system consists of a filament-wound fiberglass carrier pipe surrounded by polyurethane insulation jacketed with a PVC pipe.

The installation of the St. Mary's Hospital geothermal space and domestic water heating system has been completed and is now in full operation. Ribbon-cutting ceremonies and dedication were held on October 24, 1980.

The system is functioning properly, and the monitoring phase of the project is in progress. In addition to providing heat to the $7432-\mathrm{m}^{2}$ $\left(80,000-\mathrm{ft}^{2}\right)$ existing building, the geothermal system, with a heat pump, will also provide heat to the new $6503-\mathrm{m}^{2}\left(70,000-\mathrm{ft}^{2}\right)$ hospital building, which has just been completed. The geothermal system provides all space heating down to $-12.2^{\circ} \mathrm{C}$ $\left(10^{\circ} \mathrm{F}\right)$ and domestic hot water and boiler water preheat up to $37.8^{\circ} \mathrm{C}\left(100^{\circ} \mathrm{F}\right)$.

Diamond Ring Ranch, Haakon County, South Dakota. Geothermal water from an artesian well that has flowed since 1959 is being used for grain drying and space heating on the Diamond Ring Ranch in South Dakota. The system retrofit consists of PVC pipelines connecting the wellhead to the various structures requiring heat. After flowing through the central heat exchanger, the geothermal fluid is used as stock water and then discharged into a reservoir system used for both geothermal well and runoff catchment.

The geothermal space heating and grain drying system has been completed and is now in full operation. Ribbon-cutting ceremonies and dedication were held on October 24, 1980.

The system is functioning properly, and the monitoring phase of the project is in progress. Problems of air pockets in the main supply line have been corrected by installing air vents in the 
first two high points of the supply line. In addition, the wellhead was refurbished and the wellhead leaks were stopped.

Elko, Nevada. The Elko Geothermal Project involves the location and drilling of a production well to extract hydrothermal fluids for direct application. These fluids are to be used for process heat in a commercial laundry and for space heating a motor hotel and a bank building.

The Resource Assessment Phase has been completed. This phase included shallow temperature probe surveys, geological reconnaissance, electrical resistivity soundings, sling ram soundings, and geochemical sampling of city wells and the Elko Hot Springs. In addition, four temperaturegradient holes were drilled to further identify possible production-hole drilling sites. Test Hole

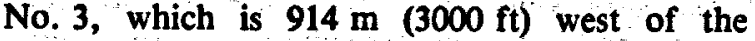
Stockmen's Motor Hotel, has been chosen as the most likely production well site. At Test Hole No. 3, temperatures in excess of $71^{\circ} \mathrm{C}\left(160^{\circ} \mathrm{F}\right)$ were encountered at a depth of $172 \mathrm{~m}$ ( $565 \mathrm{ft})$.

The Elko Heat Company has awarded a contract to Hackworth Drilling of Elko, Nevada, for the production well drilling.

The permitting phase of the project is now in progress. The state engineer inspected two drill sites and overruled all filed protests. However, a permit application filed later to change the point of water diversion must still go through 5 weeks of publication and a 30 -day protest filing period before being considered by the Nevada State Engineer. Approval is expected in June, and drilling will start shortly thereafter.

Warm Springs State Hospital, Montana. This project would develop the geothermal resource at Warm Springs (near Butte, Montana) to provide domestic water and space heating at the Warm Springs State Hospital. Water from the production well would be pumped through two plate-type heat exchangers and discharged into a wetlands disposal area.

After drilling, initial well tests indicated considerable well bore damage: However, due to test pump malfunctions, long-term drawdown tests could not be conducted. The failed shaft-type test pump was removed.
By the last month of the report period, artesian flow had decreased to $1.26 \mathrm{~L} / \mathrm{s}(20 \mathrm{gpm})$, and a well development program was started in March 1981.

Attempts to deepen the well with a cable tool rig failed when an obstruction was encountered at the bottom of the well. A fishing attempt also failed. The lower $36.6 \mathrm{~m}$ (120 ft) of solid liner was perforated, and the well was swabbed and bailed for one week. A television camera survey was run to $331.01 \mathrm{~m}(1086 \mathrm{ft})$ before the camera failed. Well screen was not installed.

Artesian flow was improved to $2.65 \mathrm{~L} / \mathrm{s}$ (42 $\mathrm{gpm}$ ). A submersible pump will be used to flow test the well.

Pagosa Springs, Colorado. The geothermal resource in Pagosa Springs has been in limited use since the early 1900 s. Nearly 30 wells have been drilled for heating and recreational purposes. Flow and disposal rights from some of these wells will be transferred to the demonstration project's district heating system. Many of the town's public buildings will be heated by the geothermal energy, and provision for connecting commercial and residential buildings to the system will be made.

Two wells will be used to supply the system-PS-3 at $55^{\circ} \mathrm{C}\left(131^{\circ} \mathrm{F}\right)$ and PS-5 at $65^{\circ} \mathrm{C}$ $\left(149^{\circ} \mathrm{F}\right)$. The wells were simultaneously flow tested, Well PS-3 at $12.6 \mathrm{~L} / \mathrm{s}(200 \mathrm{gpm})$ and Well PS-5 at $44.2 \mathrm{~L} / \mathrm{s}(700 \mathrm{gpm})$ for about seven days. The reservoir capacity appears adequate for the peak $63.09 \mathrm{~L} / \mathrm{s}$ (1000 gpm) district heating system.

The final project design was reviewed in January 1981. In February, EG\&G Idaho and CH2M Hill, Inc., worked with the project team in detailing electrical requirements for the bid package. The final bid package was received March 18, and DOE-ID's concurrence letter was issued March 27. The construction bid package was released March 31 with an April 30 closing date.

Utah Roses, Sandy, Utah. The Utah Roses greenhouse complex is located - in the town of Sandy, which is approximately $17 \mathrm{~km}$ (11 mi) south of Salt Lake City, Utah. The complex consists of $23,500 \mathrm{~m}^{2}$ (6 acres) of greenhouses that 
produce cut roses for the national floral market. A production well drilled to a depth of $1525 \mathrm{~m}$ $(5009 \mathrm{ft})$ produces water at a pumped flow rate of $12.6 \mathrm{~L} / \mathrm{s}(200 \mathrm{gal} / \mathrm{min})$ and a temperature of $50^{\circ} \mathrm{C}$ $\left(122^{\circ} \mathrm{F}\right)$ with a drawdown of about $366 \mathrm{~m}$ (1200 ft).

The geothermal water will be piped through water-to-air heat exchangers, and the heated air will be distributed in large, thin-film polyethylene tubes throughout the greenhouse. The water will then be piped in the ground alongside the plants to use the maximum amount of available heat.

Progress during this report period was limited to resolving the permit process for disposal of up to $12.6 \mathrm{~L} / \mathrm{s}(200 \mathrm{gpm})$ of geothermal effluent (with $2700 \mathrm{mg} / \mathrm{L}$ total dissolved solids) to the Jordan River via the Galena Canal. A study of the chemical content of the Galena Canal and the Jordan River and of their dilution characteristics after discharge of geothermal effluent concluded that there would be no significant impact to either of the water bodies. The study was presented to the Utah Pollution Control Board, which concurred and approved the application for surface disposal. A National Polluting Discharge Elimination System (NPDES) permit was submitted in December 1980 to the EPA regional office in Denver. The application was reviewed and was published in March, 1981. During the 30-day public notice period that followed, no formal challenge of the action was recorded. The permit is to be issued early in June 1981 .

Utah State Prison, Draper, Utah. The Utah State Prison is located in Salt Lake County approximately $27 \mathrm{~km}(17 \mathrm{mi})$ south of Salt Lake City. The resource surface expression, known as Crystal Hot Springs, is adjacent to the prison. A geothermal well has recently been drilled at the springs for a commercial greenhouse project and produces water at $88^{\circ} \mathrm{C}\left(190^{\circ} \mathrm{F}\right)$ and an artesian flow rate of $12.6 \mathrm{~L} / \mathrm{s}(200 \mathrm{gpm})$ the project would retrofit the minimum security section of the prison to use the heat from such a well.

The existing forestry well (SF-1) was deepened from $85.3 \mathrm{~m}(280 \mathrm{ft})$ to $152 \mathrm{~m}(500 \mathrm{ft})$, and a new test well (USP/TH-1) was drilled to $306 \mathrm{~m}$ (1005 ft) on Utah State Prison property. When opened for four days, SF-1 artesian flowed $38.9 \mathrm{~L} / \mathrm{s}(250 \mathrm{gpm})$ at $80^{\circ} \mathrm{C}\left(176^{\circ} \mathrm{F}\right)$. USP/TH-1 artesian flowed for 15 hours at $37.8 \mathrm{~L} / \mathrm{s}$
(600 gpm). Then it had to be reduced to $25.2 \mathrm{~L} / \mathrm{s}$ $(400 \mathrm{gpm})$ for 11.5 hours. The temperature was about $75^{\circ} \mathrm{C}\left(167^{\circ} \mathrm{F}\right)$.

A subcontract was signed between the Utah Energy Office and the State Building Board (SBB) for the supervision of design and construction, and negotiations for a subcontract for preliminary design were started between the SBB and $\mathrm{CH} 2 \mathrm{M}$ Hill.

Madison County, Idaho. The Madison County Geothermal Project plans to demonstrate a lowtemperature geothermal resource for food processing and district space heating.

Two production wells at 914 and $1829 \mathrm{~m}$ (3000 and $6000 \mathrm{ft}$ ) were proposed. The deep well was expected to supply $121^{\circ} \mathrm{C}\left(250^{\circ} \mathrm{F}\right)$ water to a potato processing company for use in food processing, followed by cascading use for space heating with an $88^{\circ} \mathrm{C}\left(190^{\circ} \mathrm{F}\right)$ supply temperature.

It was decided to drill a 914- to 1524-m (3000- to 5000-ft) production well (MCG-1) near the previously drilled thermal gradient hole, HTW-1, at the junction of major faults near Rexburg, Idaho. Intersection of the fault was predicted to be between 762 and $914 \mathrm{~m}$ (2500 and $3000 \mathrm{ft}$ ).

Well MCG-1 was drilled to $1199 \mathrm{~m}(3933 \mathrm{ft})$, but the water temperature never exceeded $21.7^{\circ} \mathrm{C}$ $\left(71^{\circ} \mathrm{F}\right)$. A $3.8 \mathrm{~L} / \mathrm{s}(60 \mathrm{gpm})$ downward flow $\operatorname{ran}$ from 731 to $853 \mathrm{~m}$ ( 2400 to $2800 \mathrm{ft}$ ) where the hole had sluffed in and bridged across after drilling. It was postulated that warm lower zones may be masked by the cold downward flow, particularly

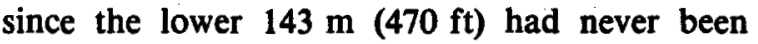
logged.

During the report period, DOE-ID accepted a proposal to reopen the hole to $1199 \mathrm{~m}(3933 \mathrm{ft})$, line it, and $\log$ it. Planning for this work was done, but performance is delayed until early May 1981 when water again becomes available from the nearby irrigation canal.

Boise, Idaho. The objective of the Boise City/Boise Warm Springs Water District (BWSWD) Geothermal Project is to develop a geothermal space heating system to serve the largest possible commercial and residential market in the Boise central business district and neighboring residential areas. 
Engleman Well Drilling of Nampa, Idaho, was awarded a unit price contract to drill the $152 \mathrm{~m}$ $(500 \mathrm{ft}$ ) BWSWD No. 3 well. Drilling with a cable tool rig began on January 9, 1981. As of March 31, the well was at $126 \mathrm{~m}(412 \mathrm{ft})$. The temperature was measured at $49^{\circ} \mathrm{C}\left(120^{\circ} \mathrm{F}\right)$ at

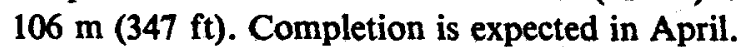

Boise Geothermal Ltd., (drilling partnership) raised a portion of the required funds to drill three to five wells in the Military Reserve Park. To cover the balance, they applied for a federally guaranteed loan under the DOE Geothermal Loan Guaranty Program. Review of the toan application began in March 1981 by EG\&G Idaho in cooperation with DOE-SAN. The review will be completed in April.

The partners began drilling the Boise City No. 1 well (near the present Beard well) on March 24. By March 31, the well was drilled to $273 \mathrm{~m}(896 \mathrm{ft}$ ) of a planned $457 \mathrm{~m}(1500 \mathrm{ft})$ using a rotary rig. Production casing, $30.48 \mathrm{~cm}$ (12 in.) in diameter, was set and cemented to $266 \mathrm{~m}$ (874 ft).

The schedule for the project has been revised. Startup of the Boise City and BWSWD systems is expected for the 1982-83 heating season. Final design began in March 1981, one month ahead of the revised schedule.

The final modification of the cooperative agreement was delivered to the Division of Geothermal Energy, DOE, on January 30, 1981. The modification was approved pending the final authorization of DOE funding. The modified contract defines a $\$ 7.1$ million project, with $\mathrm{DOE}$ sharing $\$ 4.2$ million of the cost.

\section{PRDA Projects}

Direct Application of Geothermal Energy at the L'eggs Products Plant, Las Cruces, New Mexico. The Energetics Corporation of Dallas, Texas, conducted a study to evaluate five potential geothermal resource areas for use in the L'eggs Plant processes. The final report for the completed study was approved and published.

Direct Application of Geothermal Energy for Ethanol Production for Automotive Fuel Usage. Bechtel National, Inc, completed the study to evaluate the Raft River, Idaho, geothermal resource for use in producing ethanol. A
$76 \times 10^{6} \mathrm{~L}\left(20 \times 10^{6} \mathrm{gal}\right)$ per year facility using potatoes, wheat, and sugar beets as feedstocks has been designed. The final report for the study was approved and published.

Evaluation of Direct Hot Water Geothermal Applications on the University of New Mexico Campus. The object of this project was to determine the economic and engineering feasibility of heating and cooling approximately $25 \%$ of the university campus with lowtemperature geothermal energy. The final report for the completed study was approved and published.

Municipal Geothermal Heat Utilization Plan for Glenwood Springs, Colorado. The objective of this study was to assess the economic and engineering feasibility of supplying geothermal heat to several city buildings and a municipal wastewater-treatment facility. The final report for the completed study was approved and published.

Geothermal Space Heating in Poplar, Montana. This study was conducted by PRC Toups, Inc., and the Council of Energy Resource Tribes. The primary objective of the project was to define the feasibility of using the Madison Aquifer resource for district heating in the Poplar Dome area. The completed and approved final report was published.

Engineering, Marketing, and Economic Study of a 4.5 Million-Gallon Geothermal Fuel Alcohol Plant for the Vale Geopark Site. For Technology International; Inc., the objectives of this project are to drill a 1500-ft well for resource assessment, determine economic and institutional factors, and generate a preliminary design for a fuel alcohol plant. The period of performance for this cooperative agreement is from January 1981 to December 1981. The contract award meeting was held in Denver, Colorado, in January.

EG\&G Idaho and DOE-ID personnel inspected the resource site in March and received an application for environmental approval to drill three to five thermal gradient wells. Page Brothers Drilling Co. was selected from among three bids. Resource literature was evaluated. A magnetometer survey was done, and a laboratory evaluation of feedstocks was started. The management plan was received by EG\&G and DOE-ID. 
Resource, Engineering, and Economic Study for Direct Heat Applications of Geothermal Energy at the Salida (Colorado) Geothermal Project. For Chaffee Geothermal, Ltd., the objective of this study is to study direct heat application of the Poncha Springs-Salida Geothermal Prospect to the industrial process heat requirements of CoZinCo, Inc., and to other prospective energy users in Salida.

The period of performance for the cooperative agreement is January 1981 to November 1981. The contract award meeting was held in February 1981 in Denver. Resource characterization, engineering considerations, and economic tasks were started during the report period.

Commercial Production of Ethanol in the San Luis Valley, Colorado. For Westec Services/ McCulloch Geothermal Corp., the objective of this study is to investigate the feasibility of using geothermal energy in the San Luis Valley, Colorado, to provide all or part of the total energy requirements of a $75-$ to 190 -million $\mathrm{L} / \mathrm{yr} 20$ - to 50-million (gpy) ethanol production plant.

The current period of performance for this cooperative agreement is from January 1981 to September 1981. A request for a time extension to November 1981 is pending. The contract award meeting was held in February 1981.

The project team concentrated on a data search for state-of-the-art ethanol production. It was determined that to conduct an ethanol plant optimization assessment of capital cost and its sensitivity to changes in resource parameters and feedstocks, a computer code should be used. The feasibility of generating such a code was investigated since codes of this type are not available. A proposal to generate the code was submitted to DOE.

Resource characteristics were estimated. The consensus is that a temperature of $150^{\circ} \mathrm{C}\left(302^{\circ} \mathrm{F}\right)$ is probable, but this will require confirmation.

Resource, Engineering, and Economic Study for the Great Western Malting Co. Geothermal Project. For Trans Energy Systems, Inc., the objective of this study is to determine if drilling wells and constructing a heat recovery system to use geothermal energy in processing barley malt is justified. The period of performance for the cooperative agreement is from December 1980 to December 1981. The contract award meeting was held in January.
Characterization of the resource began. Temperature logs from three plant site water wells and one nearby geothermal well (Whitewater Well, Energy Services) were run. Electromagnetic and gravity measurements were conducted to define subsurface faulting.

Three heat conversion methods were evaluated for the barley drying process: heat pumps, booster boiler, and air preheater. From preliminary estimates of the resource characteristics, $65.5^{\circ} \mathrm{C}\left(150^{\circ} \mathrm{F}\right) 31.54 \mathrm{~L} / \mathrm{s}$ $(500 \mathrm{gpm})$, the air preheater method was the most effective from cost and technical standpoints.

Environmental and safety factor assessments were started.

Research and Development of Information on Geothermal Direct Heat Application Projects. For ICF, Inc., the objectives of this study are to compile data for geothermal direct-use projects; evaluate and analyze the data for selected issues; identify and, if possible, circumvent barriers to development; and report on the project.

The period of performance for this contract is from October 1980 to September 1983. The contract award meeting was held in Washington, D.C., in October.

Data collection began with the DOE-ID administered PON projects. Economic analyses were made on the St. Mary's project to refine the methodology and level of cost detail needed. Contacts were made with DOE/SAN and DOE-NV in preparation for obtaining data on the projects under their cognizance.

\section{M-X/RES- GEOTHERMAL APPLICATIONS DEVELOPMENT}

\section{(T. W. Lawford and M. K. Shane)}

The use of geothermal energy is being considered as one of several renewable energy systems to provide electrical power and space conditioning for portions of the M-X missile system. DOE/ID and DOE/NV are responsible for the geothermal resource assessment and applications development 
tasks. EG\&G and the Earth Science Laboratory of the University of Utah Research Institute (ESL/UURI) are serving as the primary support contractors to DOE/ID, with EG\&G having the basic responsibility for the Geothermal Applications Development portion of the task and ESL/UURI having the basic responsibility for the Geothermal Assessment portion of the task.

The Phase I objective of the EG\&G task is to sufficiently quantify the characteristics of geothermal applications to the M-X project to allow appropriate decisions to be made on the extent of geothermal use in the overall Renewable Energy Systems (RES) package. The characteristics to be defined are performance, cost, socioinstitutional issues, systems implementation planning, and system configurations (design). The output characteristics of geothermal application systems are to be melded with similar solar and wind system characteristics to develop a recommendation on the overall RES configuration by Aerospace, Inc.

Future Phase II tasks will be initiated after the decisions have been made by the Government concerning the RES "mix." These tasks will involve selection of plant sites and application concepts, work on conceptual designs for the selected sites, contractual assistance to the Government in the selection of architectural/engineering firms for Title I, II, and III design, contractual assistance to the Government in the selection of construction contractors, preliminary specifications for equipment, systems acquisition planning, etc.

Specific accomplishments during this reporting period have been involved with project management-including task definition, planning, and coordination - and with concept definition-including scenarios for the use of geothermal energy and development of generic parameters for electric power production and for space conditioning. In the area of electric power production, work is being performed on generic plant and system studies of advanced binary power plants. The best candidate hydrocarbon working fluids have been identified, and heat balances have been generated for $20 \mathrm{MW}(\mathrm{e})$ power plants in the temperature ranges expected at the operating base locations. Figure 6 illustrates the performance levels to be expected from "conventional" binary and dual-flash steam plants and contrasts these with expected performance levels for the advanced binary plants using working fluid mixtures being developed for M-X uses. A cycle schematic for the advanced binary cycles, which use geothermal wells produced in the flashing flow mode, is given in Figure 7. The cycle state points for a geothermal temperature of $400^{\circ} \mathrm{F}$ are given in Table 1 . In addition, work is being performed on a hybrid fossil fuel/geothermal configuration as a possible alternative to a pure geothermal plant. Various heat rejection systems are being evaluated that could eliminate the need for wet cooling towers.

In the area of geothermal space conditioning systems, the primary effort is being directed toward systems that could be used at the Milford operating base in southwest Utah because sitespecific resource information on this base will probably be received in time to influence the selection of the energy source. Systems concepts have been developed, the systems are being evaluated, and cost surfaces are being developed as a function of resource characteristics. These space conditioning sýsterns include an evaluation of air conditioning possibilities as well as of space heating. 


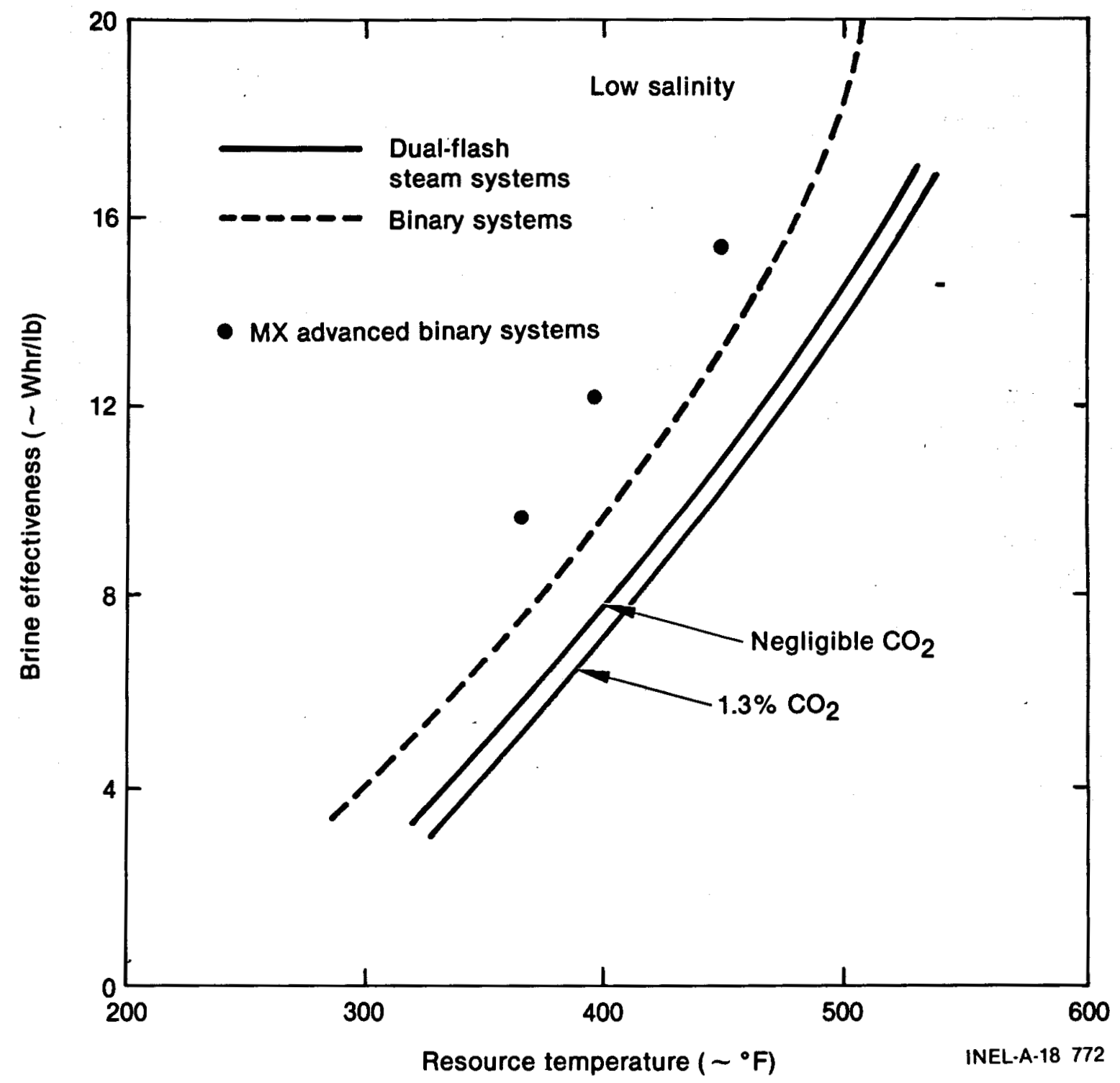

Figure 6. Net brine effectiveness-performance levels of conventional binary and dual-flash steam plants contrasted with those expected for advanced binary plants using fluids developed for M-X. 


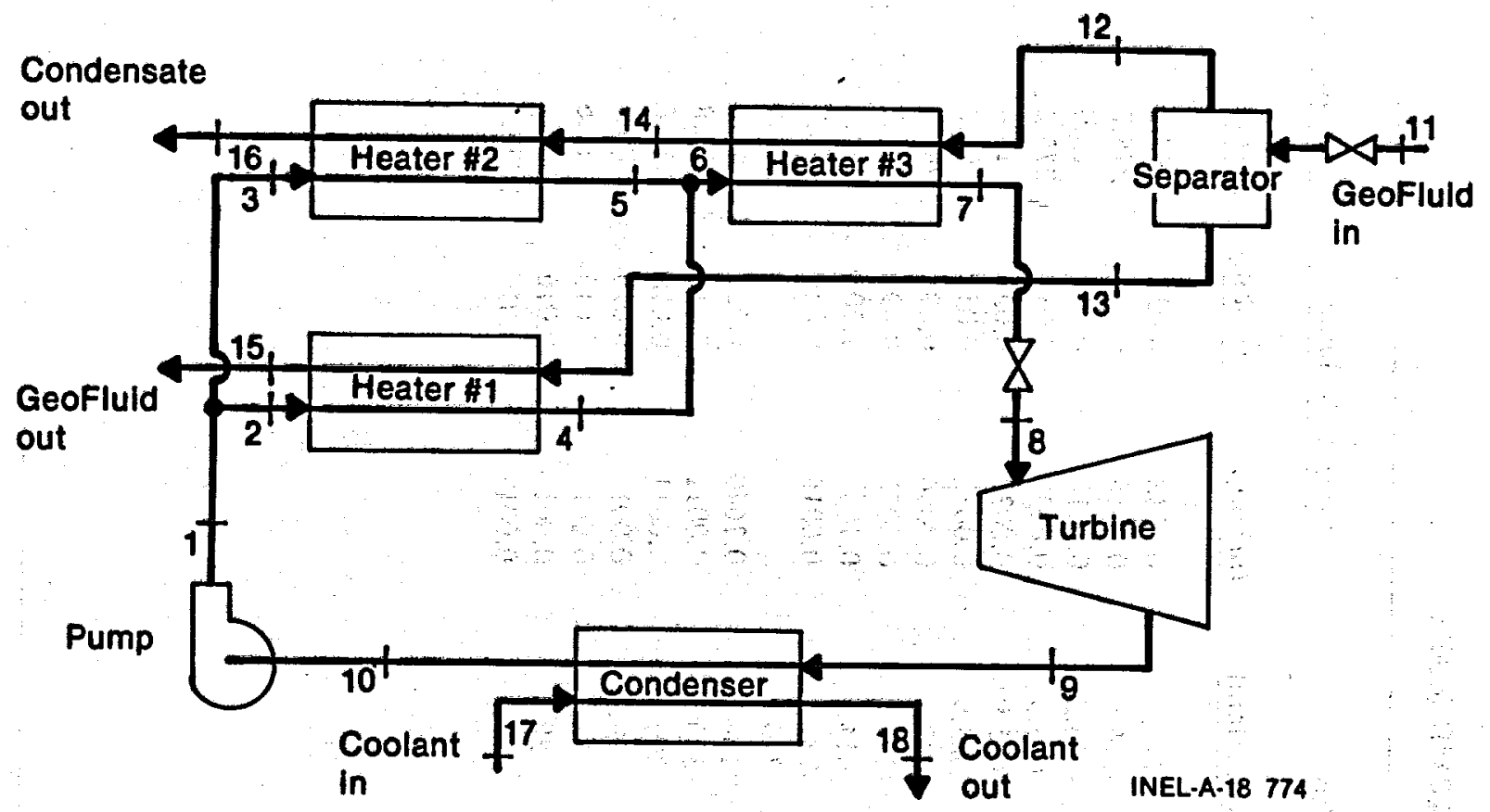

Figure 7. Cycle schematic for 20-MW(e) geothermal electric plant. 
Table 1. Cycle state points for a geothermal temperature of $204^{\circ} \mathrm{C}\left(400^{\circ} \mathrm{F}\right)$

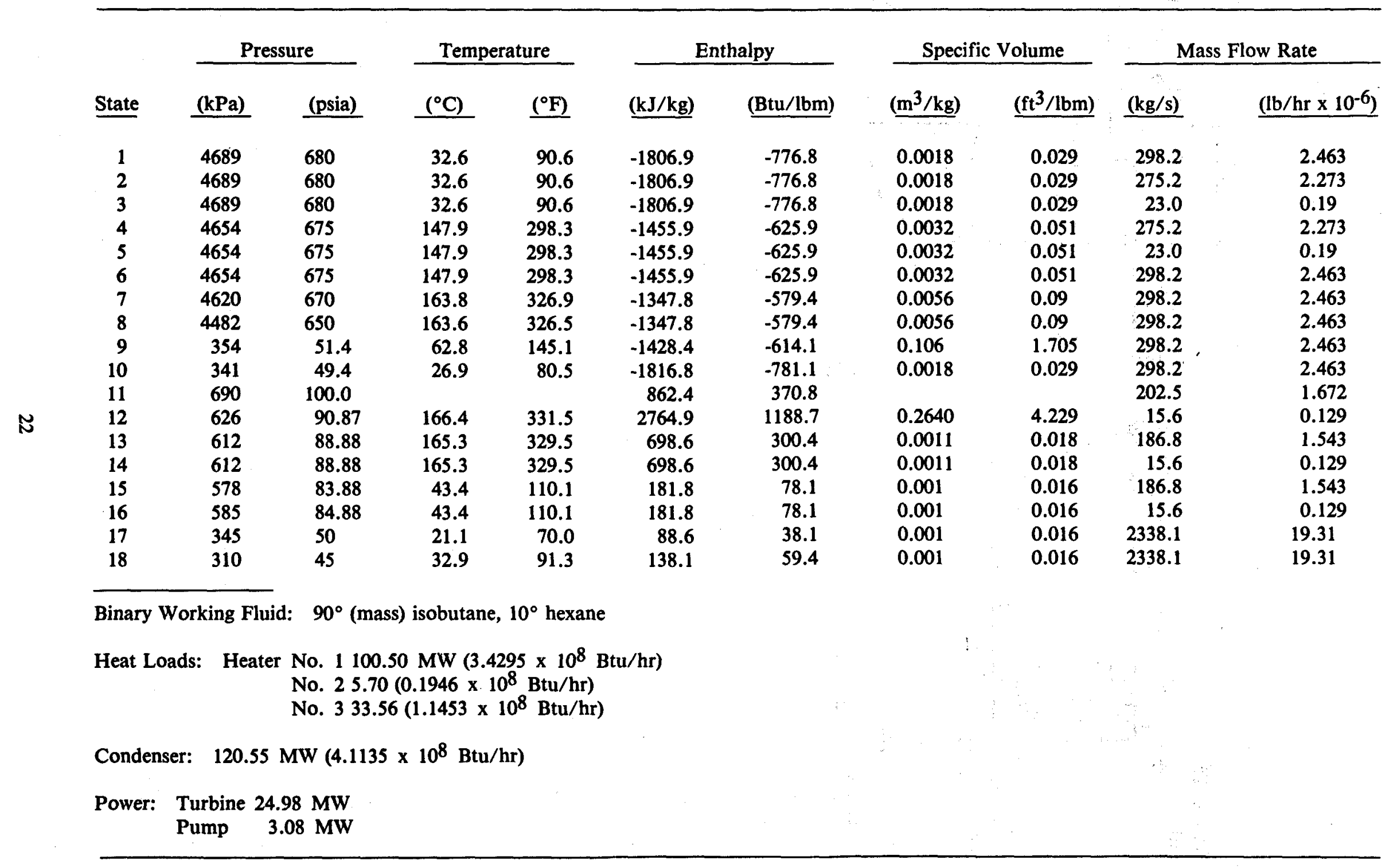




\section{APPENDIX A}

\section{PUBLICATIONS OF THE IDAHO GEOTHERMAL PROGRAM}



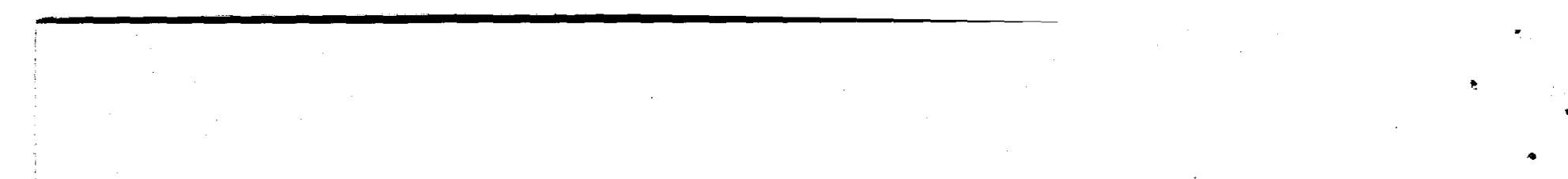


\section{APPENDIX A}

\section{PUBLICATIONS OF THE IDAHO GEOTHERMAL PROGRAM}

Table A-1 lists the formal reports published by EG\&G Idaho, Inc., for the Idaho Geothermal Program. Printed or microfiche copies of these reports may be ordered from the National
Technical Information service, U.S. Department of Commerce, 5285 Port Royal Road, Springfield, Virginia 22161.

Table A-1. EG\&G Idaho, Inc., formal reports of the Idaho Geothermal Program

\begin{tabular}{|c|c|c|c|}
\hline $\begin{array}{c}\text { Report } \\
\text { Number }\end{array}$ & Author & Date & Title \\
\hline TREE-1008 & J. F. Kunze, ed. & $10-76$ & $\begin{array}{l}\text { Geothermal R\&D Project Report for Period } \\
\text { April } 1,1976 \text { to June } 30,1976\end{array}$ \\
\hline TREE-1016 & J. F. Kunze & $1-77$ & $\begin{array}{l}\text { The Potential for Utilizing Geothermal Energy for } \\
\text { Space Heating in Reconstructed Sugar City, Idaho }\end{array}$ \\
\hline TREE-1023 & D. T. Neil & $11-76$ & $\begin{array}{l}\text { Geothermal Shell and Tube Heat Exchanger } \\
\text { Augmentation }\end{array}$ \\
\hline TREE-1030 & J. F. Kunze & $12-76$ & $\begin{array}{l}\text { Geothermal R\&D Project Report for Period July 1, } \\
1976 \text { to September } 30,1976\end{array}$ \\
\hline TREE-1039 & I. J. Ingvarsson et al. & $12-76$ & $\begin{array}{l}\text { Determination of the 5-MW Gross Nominal Design } \\
\text { Case Binary Cycle for Power Generation at Raft } \\
\text { River, Idaho }\end{array}$ \\
\hline TREE-1048 & R. C. Schmitt et al. & $1-77$ & $\begin{array}{l}\text { Beneficial Uses of Geothermal Energy Description } \\
\text { and Preliminary Results for Phase I of the Raft } \\
\text { River Irrigation Experiment }\end{array}$ \\
\hline TREE-1085 & W. C. Kettenacker & $3-77$ & $\begin{array}{l}\text { Two-Dimensional Simulation of the Raft River } \\
\text { Geothermal Reservoir and Wells }\end{array}$ \\
\hline TREE-1108 & I. J. Ingvarsson et al. & 4-77 & $\begin{array}{l}\text { Working Fluid and Cycle Selection Criteria for } \\
\text { Binary Geothermal Power Plants with Resource } \\
\text { Temperatures in the Range of } 200 \text { to } 400^{\circ} \mathrm{F}\end{array}$ \\
\hline TREE-1112 & S. E. Turner & 4-77 & $\begin{array}{l}\text { HECDOR-A Heat Exchanger Cost and Design } \\
\text { Optimization Routine }\end{array}$ \\
\hline TREE-1114 & J. F. Kunze et al. & 4-77 & $\begin{array}{l}\text { Asbestos-Cement Pipeline Experiment at the Raft } \\
\text { River Geothermal Project }\end{array}$ \\
\hline TREE-1134 & J. F. Kunze & $5-77$ & $\begin{array}{l}\text { Geothermal R\&D Project Report for Period } \\
\text { October } 1,1976 \text { to March } 31,1977\end{array}$ \\
\hline TREE-1162 & L. L. Mink et al. & $10-77$ & Geothermal Potential of the West Boise Area \\
\hline
\end{tabular}




\begin{tabular}{|c|c|c|c|}
\hline $\begin{array}{l}\text { Report } \\
\text { Number }\end{array}$ & Author & $\underline{\text { Date }}$ & Title \\
\hline TREE-1164 & C. J. Shaffer & $8-77$ & $\begin{array}{l}\text { Floating Power Optimization Studies for the Cool- } \\
\text { ing System of a Geothermal Power Plant }\end{array}$ \\
\hline TREE-1176 & R. L. Miller & $10-77$ & $\begin{array}{l}\text { Results of Short-Term Corrosion Evaluation Test } \\
\text { at Raft River }\end{array}$ \\
\hline TREE-1182 & I. A. Engen & $2-78$ & $\begin{array}{l}\text { Residential Space Heating Cost: Geothermal vs } \\
\text { Conventional Systems }\end{array}$ \\
\hline TREE-1256 & J. F. Kunze & 3-78 & $\begin{array}{l}\text { Geothermal R\&D Project Report for Period } \\
\text { April } 1,1977 \text { to September } 30,1978\end{array}$ \\
\hline TREE-1278 & G. L. Blake, ed. & $7-78$ & $\begin{array}{l}\text { Semiannual Progress Report for the Idaho } \\
\text { Geothermal Program, October 1, } 1977 \text { to } \\
\text { March 31, } 1978\end{array}$ \\
\hline TREE-1295 & G. L. Blake, ed. & $11-78$ & $\begin{array}{l}\text { Semiannual Progress Report for the Idaho } \\
\text { Geothermal Program April } 1 \text { to September } 30 \text {, } \\
1978\end{array}$ \\
\hline TREE-1312 & J. F. Whitbeck et al. & $1-79$ & $\begin{array}{l}\text { Measurement and Control Techniques in } \\
\text { Geothermal Power Plants }\end{array}$ \\
\hline TREE-1340 & S. G. Spencer et al. & $4-79$ & $\begin{array}{l}1978 \text { Annual Report, INEL Geothermal } \\
\text { Environmental Program }\end{array}$ \\
\hline TREE-1359 & L. F. Burdge et al. & $10-79$ & $\begin{array}{l}\text { Semiannual Progress Report for the Idaho } \\
\text { Geothermal Program, October 1, } 1978 \text { to } \\
\text { March 31, } 1979\end{array}$ \\
\hline TREE-1365 & O. J. Demuth & $7-79$ & $\begin{array}{l}\text { Analysis of Binary Thermodynamic Cycles for a } \\
\text { Moderately Low-Temperature Geothermal } \\
\text { Resource }\end{array}$ \\
\hline TREE-1370 & J. F. Sullivan et al. & $9-79$ & $\begin{array}{l}\text { Raft River Geothermal Aquaculture } \\
\text { Experiment-Phase II }\end{array}$ \\
\hline EGG-2001 & $\begin{array}{l}\text { S. G. Spencer } \\
\text { B. F. Russell } \\
\text { J. F. Sullivan }\end{array}$ & $9-79$ & $\begin{array}{l}\text { Vol. } 1 \text { - Potential Use of Geothermal Resources } \\
\text { in the Snake River Basin: An Environmental } \\
\text { Overview }\end{array}$ \\
\hline & & & Vol. 2 - Annotated Bibliography \\
\hline EGG-2005 & $\begin{array}{l}\text { N. E. Stanley } \\
\text { R. C. Schmitt }\end{array}$ & $1-80$ & $\begin{array}{l}\text { Effects of Irrigation on Crops and Soils with Raft } \\
\text { River Geothermal Water }\end{array}$ \\
\hline EGG-2010 & R. R. Ihrig, ed. & $3-80$ & $\begin{array}{l}\text { Semiannual Progress Report for the Idaho } \\
\text { Geothermal Program April } 1 \text { to September } 30,1979\end{array}$ \\
\hline
\end{tabular}


Table A-1. (continued)

\begin{tabular}{|c|c|c|c|}
\hline $\begin{array}{l}\text { Report } \\
\text { Number }\end{array}$ & Author & Date & Title \\
\hline EGG-2013 & J. G. Keller & $3-80$ & $\begin{array}{l}\text { Geothermal Direct Applications Hardware Systems } \\
\text { Development and Testing - } 1979 \text { Summary Report }\end{array}$ \\
\hline EGG-2028 & T. L. Thurow & $4-80$ & $\begin{array}{l}1979 \text { Annual Report INEL Geothermal } \\
\text { Environmental Program }\end{array}$ \\
\hline EGG-2029 & $\begin{array}{l}\text { N. E. Stanley } \\
\text { T. L. Thurow } \\
\text { B. F. Russell } \\
\text { J. F. Sullivan }\end{array}$ & $5-80$ & $\begin{array}{l}\text { Geothermal Wetlands: An Annotated Bibliography } \\
\text { of Pertinent Literature }\end{array}$ \\
\hline EGG-2034 & R. R. Ihrig & $7-80$ & $\begin{array}{l}\text { Semiannual Progress Report for the Idaho } \\
\text { Geothermal Program October 1, } 1979 \text { to March 31, } \\
1980\end{array}$ \\
\hline EGG-2036 & $\begin{array}{l}\text { L. T. Cole } \\
\text { R. C. Schmitt }\end{array}$ & $6-80$ & $\begin{array}{l}\text { Fluidized-Bed Potato Waste Drying Experiments at } \\
\text { the Raft River Geothermal Test Site }\end{array}$ \\
\hline EGG-2054 & $\begin{array}{l}\text { T. L. Thurow } \\
\text { C. M. White } \\
\text { R. P. Howard } \\
\text { J. F. Sullivan }\end{array}$ & $9-80$ & Raptor Ecology of Raft River Valley, Idaho \\
\hline EGG-2057 & $\begin{array}{l}\text { S. G. Spencer } \\
\text { D. M. Callan }\end{array}$ & $9-80$ & $\begin{array}{l}\text { An Analysis of the Response of the Raft River } \\
\text { Monitor Wells to the } 1979 \text { Injection Tests }\end{array}$ \\
\hline EGG-2077 & R. R. Ihrig, Ed. & $3-81$ & $\begin{array}{l}\text { Semiannual Progress Report for the Idaho } \\
\text { Geothermal Program, April } 1 \text { to September } 30,1980\end{array}$ \\
\hline EGG-2078 & O. J. Demuth & $3-81$ & $\begin{array}{l}\text { Prototype Geothermal Power Plant-Summary of } \\
\text { Operation for Automatic Run Test Phase }\end{array}$ \\
\hline
\end{tabular}




$$
\text { - - }
$$

